\title{
Ranking port state control detention remarks: professional Judgement and spatial overview
}

\author{
Efe Akyurek ${ }^{*}$ (D) and Pelin Bolat
}

\begin{abstract}
Introduction: The merchant marine fleet is under inspection by several parties to ensure maritime regulation compliance. International Maritime Organization mainly regulates the industry, and the most effective defender is indeed Port StateControl run by the regional memorandum of understandings.

Objective: This article aims to analyze all detention remarks of Paris Memoranda of Understanding (MOU) from 2013 to 2019 for EU15 countries (except Luxemburg and Austria) to guide marine industry on detainable Port State Control remarks and country risk profile.

Methods: The data of the detained vessels taken from the public website of Paris MOU and each report considered as a professional judgment that causes detention. Analytical Hierarchy Process Approach has been utilized to indicate the ranking of basic maritime regulations from the perspective of the Port State Control, and Geographic Information System (GIS) helps us to demonstrate the regional dispersion amongst EU15.

Results: Through an approach based on Analytical Hierarchy Process and demonstrating the results on GIS has been shown that almost all the country's top priorities for regulation are Safety of Life at Sea (SOLAS) and Fire Safety Systems (FSS). Moreover, a comparative demonstration of the detention percentage of each regulation to AHP results demonstrates a better understanding of EU15 countries' detention profile.

Conclusion: The results of the study can assist Port State Officers, ship crew, ship owners, and managers in presenting the facts of their inspection and able to improve themselves. The spatial analysis is also expected to guide ship owners and managers to focus their vessel's deficiencies on preventing sub-standardization.

Policymakers also utilize these reports to evaluate their inspection practices.
\end{abstract}

Keywords: Port state control, AHP, Paris MOU, GIS, Maritime regulations

\section{Introduction}

Maritime industry gains more volume each year by increasing the number of the world merchant fleet. During this enhancement, the control mechanism for compliance of international regulations comes one step further. The first concern was preventing oil pollution disasters, so Australia prohibited discharge oil into navigation areas on 1916 without an effective control mechanism [9]. In contrary, use of Samuel Plimsoll loading marks,

*Correspondence: efe.akyurek@dutchlloyd.nl

Istanbul Technical University, Maritime Faculty, Istanbul, Turkey and overloading ships become subject to detention [11]. History demonstrates many examples of great disasters that sub-standards vessels cause after these actions. So, the Port State Control for merchant vessels is evolved as a control mechanism to fight against the sub-standard ships to prevent disasters and save human life as well. The success of Port State Control to fight against substandardization for the maritime industry depends on the share of information.

The basic argument is based on the success of Port State Control Report observations. Researches show that 
$63 \%$ of vessels exhibit fewer remarks on following inspections. This fact is an important sign that enforcement of international regulations to prevent pollution and accidents is more successful in following inspections [4]. Indeed, the ultimate sanction by Port State Control to any ship concludes with a detention that executed professionally. In this context, Port State Control Officers are maritime professionals who act on behalf of maritime Administrations as decision maker. However, the detentions are also depending on inspection place where the Port State Control Officer onboards [5]. In related to this, the knowledge gap of this study relies on the different international regulations with altering concentrations of these Administrations while detaining the vessels as a result of Port State Control inspections.

This article aims to analyze Port State Control reports with Analytical Hierarchy Process (AHP) which cause vessel detention to reveal a detention profile of each EU15 country under international maritime regulations. AHP qualifies as method of this study, since the detention decision has to be performed as an expert review. The Geographic Information System (GIS) demonstration of the AHP results and percentage analysis of each regulation presents ranking for ship-owners, managers and ship crew to monitor their performances and policy makers expected become aware of their tendencies on detention decisions. By this means, novelty of this paper is to rank and demonstrate the detainable deficiencies with GIS and providing detention profile for each EU15 country in scope of international maritime regulations.

The pioneer international regulatory base for Port State Control can be accepted by The United Nations Convention on the Law of the Sea, 1958 (UNCLOS I) article 25 [9]. Amended to 1982 United Nations Convention on the Law of the Sea, the port state control appeared as an innovative tool to fight against marine pollution caused by ships, maritime safety, working and living conditions. The need for port state control arises with a lack of implementation of international standards in the shipping industry. While the International Maritime Organization regulates the industry, the dynamics of shipping constantly tries to resist. Ultimately, the Memoranda of Understanding on Port State Control developed by cooperative regional agreements and did a significant effect on international maritime regulations and standards, including the fight against pollution [14]. In another words, regional formations would come one step further since states are bonded together [9]. Therefore, Memoranda of Understanding for states was inevitable, and currently, ten (10) individuals and geographically tied together MOUs cover the majority of world coastal areas. Currently, there are 10 MOUs in the world as Paris Memorandum Secretariat, Tokyo MoU, Vina del Mar Agreement, Mediterranean MoU, Indian Ocean MoU, Riyadh MoU, Black Sea MoU, Caribbean
MoU, and Abuja MoU. Exceptionally, the United States is not under the possession of any MoU because United States Coast Guard is either part of the armed forces and inspects ships under international maritime standards.

The Memorandum of Understanding officially set right after the massive oil spill of the VLCC 'Amoco Cadiz' in March 1978. However, the current formation signed in January 1982 by fourteen European countries in Paris, France. Currently, it is not required to be a European Union country to become a member authority for Paris MOU. The Paris MOU aims to ensure the safety of life at sea, prevention of pollution by ships, and living and working conditions on the board ships. Within these goals, the organization has developed several strategies to eliminate sub-standard vessels from member Authority coastal waters. The Paris MOU currently has twenty-seven (27) member states, as two out of twenty-seven members are not European Union member countries (Table 1).

Paris MOU administration has developed various guidelines to assist related parties (including Port State Control Officers) on proper ship inspection. According to the procedures and the guidelines, a Port State Control Officer shall act under professional attitude during the inspection and determine vessel detention, if necessary, under professional judgment.

According to EMSA (European Maritime Safety Agency), over 200,000 ships are trading in European waters at any time [1]. Subject ships for inspection are too wide to take control, and it is not feasible and practicable that inspecting $25 \%$ of the ships arriving at $\mathrm{MoU}$ ports, as well. Thus, a New Inspection Regime (NIR) for Port State Control has been adopted on 1 January 2011. This system assists the Paris MOU to identify the good shipowner [22]. Not only the Inspection Regime, but the Concentrated Inspection Campaigns (CIC) also targets to increase standards for vessels and raise awareness. CIC results are also subject to several types of research to identify substandard ships [6].

In this article, the literature review section analyzes several scholarly studies that analyze Port State Control related deficiencies based on Port State Control Report data. Since the scope of the research is limited for the Paris MOU (Memorandum of Understanding) database, the data collection section briefly explains the data selection from the Paris MOU website and methodology section explains how AHP (Analytical Hierarchy Process) approach is integrated with the data and ArcGIS software.

On the other hand, registered flag and ship types are not included the analysis since all ship types and flags are subject to ship detention by Port State Control. The Port State Control Officer carries out an inspection, and according to the inspection procedures, each decision 
Table 1 Country List of the Member Maritime Authorities of Paris MOU

\begin{tabular}{llll}
\hline Belgium & Bulgaria & Canada ${ }^{(1)}$ & Croatia \\
\hline Germany & Denmark & Estonia & Finland \\
Greece & Iceland & Ireland & Italy \\
Lithuania & Malta & the Netherlands & Norway \\
Portugal & Romania & the Russian Federation ${ }^{(1)(2)}$ & Slovenia \\
Sweden & the United Kingdom & & Poland \\
\hline
\end{tabular}

Note (1): Canada and the Russian Federation are not member states of the European Union

Note (2): Russian Federation Black Sea ports are in the scope of Black Sea Memoranda of Understanding

step (inspection type, deficiencies noted, and detention) requires professional judgment. Besides, the heavy density of traffic and hub ports [3] indeed affect the number of inspections. However, Paris MOU ship inspection regime targets ships according to inspection priorities, and ships are not inspected at all port of calls. For this reason, inspection port is not predictable, thus heavy traffic is not included in scope of this study. Finally, the discussion and conclusion section explain the novelty of this research as its contribution to the existing literature together with pointing possible future studies.

\section{Background}

A successful safety analysis of ships has been carried out using a Port State Control Inspection data and concludes that about $43 \%$ of the vessels can be identified to belong to a group where inspections are effective (Ref). However, about $4.9 \%$ of PSC suitable vessels have been targeted accordingly, but they had an accident within 6 months after the port state control. Besides, $4.7 \%$ of ships had an accident onboard, yet was not inspected after the accident occurred [17]. It is a remarkable question of why $4.7 \%$ of the ships did not inspect by any Port State Control authority. Not only the coverage of Port States affects the inspection, but economics plays a crucial role too. The measured inspection costs of a port state control are USD 747 per inspection [16], and the majority of world economics is not strong enough to bear this cost.

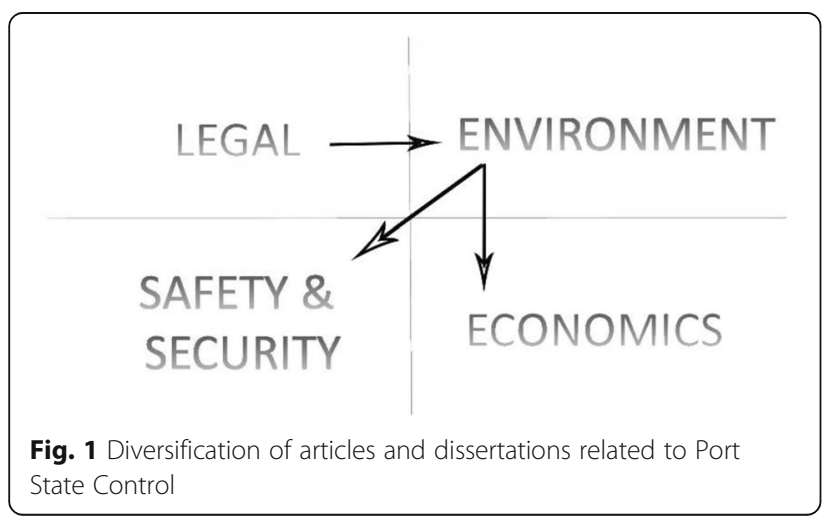

Figure 1 demonstrates the diversification of articles and dissertations related to Port State Control by the content. The earlier studies are more related to legal aspects of Port State Control on the United Nations Law on Sea (UNCLOS) aspect. Later on, Scholarly articles commonly use the Port State Control inspection reports as an output to evaluate the industry on safety \& security, pollution and, economic aspects. The conventional methodology conducted in these articles can be exemplified as; correlation analysis, Bayesian Network Model, negative binomial model, bivariate Probit model and, binary logic regression.

In the literature, the use and analysis of GIS tools are limited to analyzing Port State Control actions. Studies have much more focused on Automatic Identification System (AIS) data and their analyzes. For example, a study has been done based on data collection of ships Automatic Identification System (AIS) in Indonesia and analysis by use of AHP and GIS. The article intersected the research by assuming that the foreign-flagged vessels were probably inspected by Port State Control to determine the hazard score of the ships [19]. The original aspect of the AHP approach, uses detainable deficiency remarks of Port State Control reports to demonstrate which state focus on what specific deficiency, in general, to encourage ship owners/ managers to rectify their possible deficiencies in extreme caution.

This study aims to integrate Analytic Hierarchy Process (AHP) approach with the PSC inspection reports for each international regulation to handle and percentile of detentions then demonstrated the hierarchy of the detention criteria on Geographic Information System (GIS).

The AHP method-based articles, on the other hand, are available for analyzing Port State Control structure and actions. A three-stage methodology article aimed to restructure the PSC Authority of Taiwan by using AHP on the second stage. The study proposes that the PSC Authority shall be restructured under the Ministry of Transportation and Communications [18]. Not only the Port State Control but the maritime conventions such as ISPS (International Ship and Port Security) Code also discussed under the scope of AHP. The AHP indicates that six factors and six sub-factors are affecting 


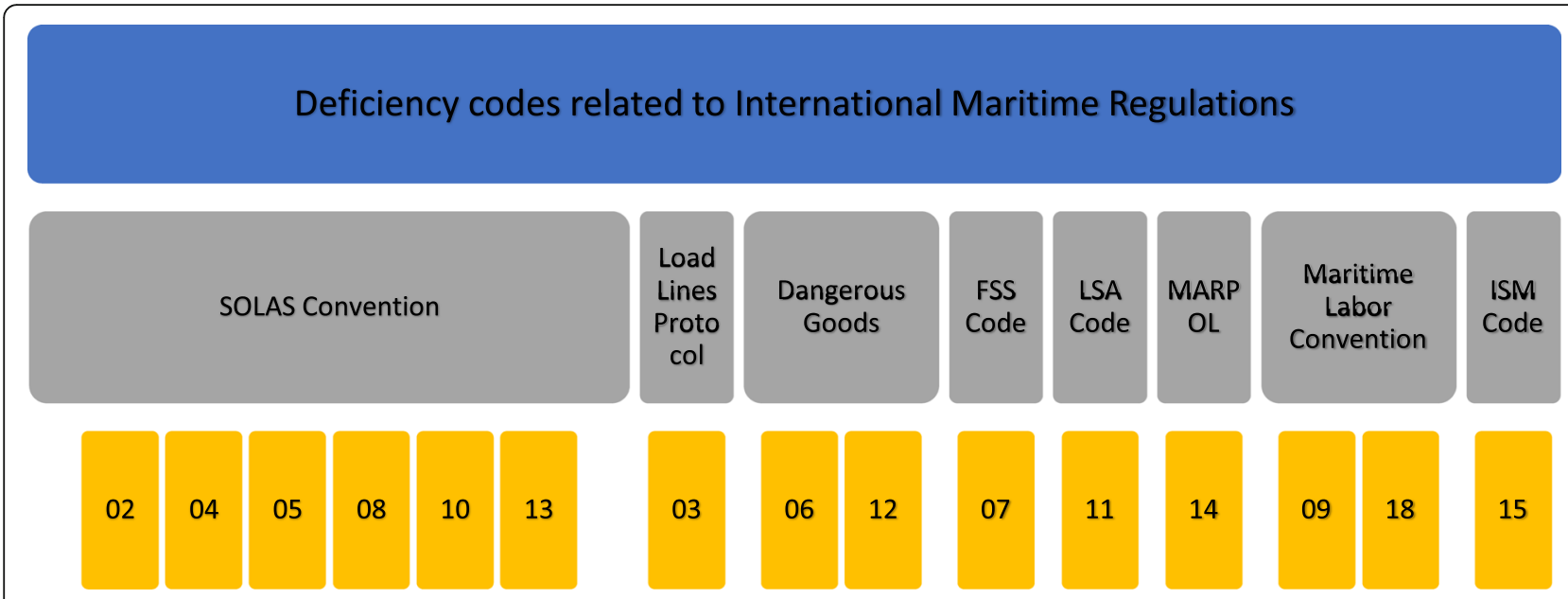

Fig. 2 The hierarchical structure of deficiency codes related to International Maritime Regulation

Indonesian maritime security, and the Government shall take severe actions for improvement [10].

The Port State Control Officer carries out an inspection, and according to the inspection procedures, each decision step (inspection type, deficiencies noted, and detention) requires professional judgment. In another perspective, the Port State Control Officer is the key person in operation who works in the field. The Officer is both initial and final determinant for the detention. This study can also be read as the continuation of the Port State Control Officer's effect on the industry. The Control Officer's background is determined by guidelines. The main point is, the PSC Officer background has an impact on vessel detentions. For instance, engineering background inspectors are more tend to detain the vessels compared to nautical background [21]. It is a fact that some detention items are open for dispute. Besides, engineer background inspectors are more careful about auxiliary machinery caused deficiencies [8]. Aside from the inspector's background, this article focuses on the professional judgment of the Port State Control Officers.

The port state control officer attends onboard and, upon completion of the inspection, delivers a report that issued under several professional judgments. According to Paris MOU Procedures on Guidance on Detention and Action Taken, the detention decision depends on the professional judgement of attending Port State Control Officer indicated as below:

When exercising professional judgement as to whether or not a ship should be detained, the PSCO will apply the following criteria:

1. Timing: ships which are unsafe to proceed to sea will be detained upon the first inspection irrespective of the time the ship will stay in port;
2. Criterion: the ship will be detained if the deficiencies on a ship are sufficiently serious to merit a PSCO returning to the ship to be satisfied that they have been rectified before the ship sails.

In this sense, all Port State Control detention remarks are accepted as a professional judgment which is essential for ranking based Analytic Hierarchy Process. The variety of detainable remarks shall indicate the root cause of detention. The domestic procedures for Port State control include the legal remarks for the detention [15]. Below aspects of literature review and existing assumptions take a role in below methodology and data selection.

\section{Methodology and data selection}

The principal Maritime Regulations have settled by SOLAS (Safety of Life at Sea) Convention after the Titanic accident. The SOLAS Convention and related regulations have been expanded with lessons learned and proactive legislation, and due to this enhancement, several chapters become an individual Code. This study will divide the regulations as follows:

- SOLAS Convention (Safety of Life at Sea),

- LL (International Convention on Load Lines),

- DG (Dangerous Goods - including International Bulk Chemical Code (IBC Code), The International Code of the Construction and Equipment of Ships Carrying Liquefied Gases in Bulk (IGC Code) and the (IMDG Code) International Maritime Dangerous Goods Code),

- LSA-Code International Life-saving Appliance Code (MSC.48(66))

- FSS Code (Fire Safety Systems Code), 
- MLC (Maritime Labor Convention, 2006 including ILO Conventions),

- MARPOL (International Convention for the Prevention of Pollution from Ships, 1973 as modified by the Protocol of 1978), and

- ISM Code (International Safety Management).

The Paris MOU list of deficiency codes is listed on the public website. The deficiency codes explain each deficiency explicitly with an explanation by its nature. The majority of the eighteen (18) general defective items are divided by their sub-items. The Port State Control deficiencies, which cause detention, have been collected from the public website and collected by its general defective items. The main point is, number 01 - Certificates and Documentation and 99 - Other deficiencies are omitted. The certificates and documentation items are complicated by including various sub-items related to multiple significant regulations described below. A similar issue is also the same for other deficiency items.

Table 2 indicates the deficiency codes (as factors) determined by Paris MOU under principal International Maritime Regulations.

During data collection, all inspection remarks have been collected from 01 January 2013 to 01 January 2019 with all detention remarks while only detainable remarks have been selected for further process. Further analysis decided to be carried out by omitting 01, 16, and 99 deficiency codes. Since the Certificates \& Documentation remark sometimes is very complicated, and even one remark may combine several principal Criteria. Related to this, 99 - Other remarks are not very well explained on the website, and the only way to get in-depth information is to check the original report for the subject ship by Port State Control Officer/s. The reason deficiency code 16 omitted is, no ship detained by this remark in the historical records. Therefore, a database has been created to sum all detainable remarks related to international maritime regulations.

After all detainable remarks have been sorted, percentage values on SOLAS, Load Line, Dangerous Goods, Fire Safety Systems, Life-Saving Appliances, MARPOL, Maritime Labour Convention, and International Safety Management codes related deficiencies are calculated to infer a general idea on overall ship detention for International Maritime Regulations aspect.

Table 3 indicates the percentage values for each regulation. According to Table 3, Greece and Italy overall detainable remark percentage is higher than in other member countries. The table also reveals that Finland has no vessel detained for regulations Load Line, Dangerous Goods, FSS Code, and MARPOL. It is another fact that the vessel traffic in Baltic Seas is not as high as the Mediterranean. Thus, percentage values many create confusion that some international regulations may not be implemented.

Table 2 Relevance matrix for Paris MOU deficiency codes with International Maritime regulations

\begin{tabular}{|c|c|c|c|c|c|c|c|c|}
\hline \multirow[t]{2}{*}{ FACTORS } & \multicolumn{8}{|c|}{ CRITERIA } \\
\hline & SOLAS & LL & DG & LSA & FSS & MLC & MARPOL & ISM \\
\hline 01 - Certificates \& Documentation & $\mathrm{x}$ & $\mathrm{x}$ & $x$ & $\mathrm{x}$ & $\mathrm{x}$ & $\mathrm{x}$ & $\mathrm{x}$ & $\mathrm{x}$ \\
\hline 02 - Structural condition & $\mathrm{x}$ & & & & & & & \\
\hline 03 - Water/Weathertight condition & & $x$ & & & & & & \\
\hline 04 - Emergency Systems & $\mathrm{x}$ & & & & & & & \\
\hline 05 - Radio communication & $\mathbf{X}$ & & & & & & & \\
\hline 06 - Cargo operations including equipment & & & $\mathrm{x}$ & & & & & \\
\hline 07 - Fire safety & & & & & $\mathrm{x}$ & & & \\
\hline 08 - Alarms & $\mathrm{x}$ & & & & & & & \\
\hline 09 - Working and Living Conditions & & & & & & $\mathrm{x}$ & & \\
\hline 10 - Safety of Navigation & $\mathrm{x}$ & & & & & & & \\
\hline 11 - Life-saving appliances & & & & $\mathrm{x}$ & & & & \\
\hline 12 - Dangerous Goods & & & $\mathrm{x}$ & & & & & \\
\hline 13 - Propulsion and auxiliary machinery & $\mathrm{x}$ & & & & & & & \\
\hline 14 - Pollution Prevention & & & & & & & $\mathbf{x}$ & \\
\hline 15 - ISM & & & & & & & & $\mathrm{x}$ \\
\hline 16 - ISPS & & & & & & & & \\
\hline 18 - MLC, 2006 & & & & & & $x$ & & \\
\hline 99 - Other & $\mathrm{x}$ & $\mathrm{X}$ & $\mathrm{X}$ & $\mathrm{X}$ & $\mathrm{X}$ & $\mathrm{X}$ & $\mathrm{X}$ & $\mathrm{X}$ \\
\hline
\end{tabular}


Table 3 Percentage values for each maritime regulation by EU15 countries (all values are in percentage)

\begin{tabular}{|c|c|c|c|c|c|c|c|c|}
\hline \multirow{2}{*}{ EU 15 Countries } & \multicolumn{7}{|c|}{ International Maritime Regulations } \\
\cline { 2 - 9 } & SOLAS & LL & DG & FSS & LSA & MARPOL & MLC & ISM \\
\hline BELGIUM & 7,13 & 16,46 & 10,45 & 6,66 & 7,01 & 4,62 & 6,62 & 5,29 \\
\hline DENMARK & 0,23 & 0 & 0 & 0,5 & 0,27 & 0,36 & 0,9 & 0,21 \\
\hline FINLAND & 0,11 & 0 & 0 & 0 & 0,09 & 0 & 0 & 0,07 \\
\hline FRANCE & 4,2 & 3,58 & 5,97 & 5,05 & 4,26 & 4,97 & 4,58 & 2,95 \\
\hline GERMANY & 6,22 & 9,66 & 10,45 & 7,93 & 3,11 & 8,53 & 5,8 & 6,32 \\
\hline GREECE & 27,82 & 26,83 & 5,97 & 17,01 & 26,97 & 13,32 & 21,98 & 17,1 \\
\hline IRELAND & 2,16 & 1,79 & 0 & 5,6 & 5,06 & 1,6 & 0,82 & 4,19 \\
\hline ITALY & 23,44 & 13,77 & 32,84 & 33,62 & 25,38 & 28,77 & 20,83 & 27,27 \\
\hline NETHERLANDS & 4,66 & 12,52 & 11,94 & 6,21 & 4,88 & 12,97 & 2,61 & 5,84 \\
\hline PORTUGAL & 2,55 & 1,61 & 0 & 1,56 & 2,22 & 1,42 & 2,12 & 2,75 \\
\hline SPAIN & 13,05 & 5,9 & 14,93 & 8,23 & 9,85 & 19,72 & 20,42 & 14,08 \\
\hline SWEDEN & 0,6 & 0,72 & 0 & 0,5 & 1,24 & 0,36 & 1,06 & 0,76 \\
\hline UNITED KINGDOM & 7,84 & 7,16 & 7,46 & 7,12 & 9,67 & 3,37 & 12,25 & 13,19 \\
\hline TOTAL & 100 & 100 & 100 & 100 & 100 & 100 & 100 & 100 \\
\hline
\end{tabular}

After demonstrating the percentage distribution of International Maritime Regulations by country, the AHP model for this article designed to be a linear network described by Saaty [24] to reach the goal of defining the importance of international maritime regulations for each country aspect as demonstrated with Fig. 2. Various multi-disciplinary examples apply AHP models for the Ship registry selection decision [13], decision making in transportation modes [12], and energy research using GIS/AHP approach [7]. The AHP methodology is also suitable to be combined with TOPSIS, VIKOR, PROMETHEE, DEMATEL, etc.

The majority of the deficiency codes are related to the SOLAS Convention means that the majority of states are tended to detain the vessels associated with SOLAS deficiencies. However, the percentage distribution of

Table 4 Relative importance table of AHP analysis [23]

\begin{tabular}{ll}
\hline Intensity of Importance & The verbal judgment of preference \\
\hline 0 & No Importance \\
1 & Very low importance \\
3 & Low importance \\
5 & Medium importance \\
7 & Strong importance \\
9 & Very strong importance \\
$2,4,6,8$ & Intermediate values between adjacent \\
& scale values \\
\hline
\end{tabular}

maritime regulations indicates that each country has a different characteristic of vessel inspection.

The total Port State Control remarks have been evaluated under a scale of below comparison matrix from 0 to 9 for each country (Table 4).

The consistency ratio (CR) as a measure inconsistency of each state found consistent. The consistency test formula is mentioned in formula 1 :

$$
C R=\frac{C I}{R I}
$$

The consistency ratio is essential since $\mathrm{CR}<0.1$ - the comparison has a consistency. The AHP results have been calculated for each country by considering the consistency ratio is below 0.1 .

\section{Analysis and results}

The AHP has been carried out by summing and categorized all detainable remarks for selected countries. For example, from 01 January 2013 to 01 January 2019, 805 detainable remarks occurred in Belgium (Table 5).

AHP has been done considering the detention remarks as a result of professional judgment (Port State Control

Table 5 Total detainable items for Belgium BELGIUM

SOLAS LOADLINE DG FSS MLC LSA MARPOL ISM TOTAL

\begin{tabular}{lllllllll}
\hline 311 & 92 & 7 & 132 & 81 & 79 & 26 & 77 & 805
\end{tabular}


Officer has decided on detention). The remarks indicate that depends on the inspection, the related remark brings detention. For example, a reefer type vessel has been detained by Belgium Port State Control on $02 \mathrm{Au}-$ gust 2013, by 07115 - Fire Dampers are not as required. However, another oil/chemical tanker did not detain on 16 November 2016 by the same remark in the same country. This difference considered as a professional judgment on the same remark under different conditions. Even though the objectivity for inspection is an essence, professional judgment may be questionable [23].

Table 6 points to the AHP on detainable items by regulations. The matrix is set considering the Analytical Hierarchy Process table by Saaty [23] under an inductive approach. Relatively, the most critical item for detention is SOLAS related deficiencies, and the importance of FSS is indeed lower than the SOLAS.

AHP results for EU 15 countries are indicated with consistency ratio.

Table 7 concludes that the majority of countries focus on SOLAS regulations as expected. However, the analysis indicates that Ireland more focused on Fire Safety Systems than SOLAS. Denmark, on the other hand, more focused on MLC than all other regulations. Further priority has been given for FSS code in general and followed by ISM Code. It may be explainable that all regulations have not been in force at the same time. For instance, the Maritime Labor Convention came in force on 20 August 2013. Still, there were several regulations by the International Labor Organization to regulate crew working, and living conditions on ships and these regulations also covered under the Maritime Labor Convention.

According to Table 8, the SOLAS Convention related deficiencies are prevailing for Paris MOU member EU15 states. The second important convention is Fire Safety Systems. Actually, Fire Safety Systems also is a subchapter for SOLAS Convention, but it is decided to divide another Code to bring this chapter more user-friendly. The third convention is the ISM Code, and the code delivered to the industry in 1995 . The ISM Code aims to regulate the operation safety for both maritime companies and ships. The MLC (formerly ILO Regulations) aims to integrate former ILO regulations to maintain a suitable working and living environment for seafarers.

\subsection{AHP and percentage demonstration on GIS}

The detention percentage is calculated by taking account of all inspection by dividing total detention on the subject state. Figure 3 shows that the detention rate for Paris MOU is higher for the Mediterranean than the other areas.

The maximum rate is in Italy, with $6 \%$ and the minimum detention rate in Finland. The majority of the Baltic Sea country's detention rate is below the EU15 average rate. The detention rates of France, Belgium, and the Netherlands are similar. Considering the traffic density in the Netherlands, Belgium, and Germany, the detention rate is the average rate for the EU15. Besides, the rate for detention is similar in Spain, Germany, Ireland, and the United Kingdom.

SOLAS Convention contains the essential regulations for the maritime industry. While Fig. 4 points the percentage for SOLAS related detentions on countries, Fig. 5 indicates each country characteristic on SOLAS related detention. This two-step GIS demonstration significate that even though a country does not detain as a result of a large number on SOLAS related deficiency, not mean that they have facilitated approach on SOLAS deficiencies. The high weight on SOLAS regulations is an expected result for AHP. Besides, the number of regulations and detainable deficiencies have a correlation. The highest weighting of the SOLAS Convention is Finland, also the overall detention percentage. Denmark gives the highest weighting for the convention by $24,0 \%$. The convention has similar weighting for Portugal, Italy, Germany, and the Netherlands.

Percentage demonstration indicate that Italy has the highest detention ratio (Fig. 6). The results of the AHP indicate that Ireland has the utmost caution on FSS Code

Table 6 Analytic Hierarchy Process on detention items at Belgium

\begin{tabular}{|l|r|r|r|r|r|r|r|l|}
\hline & \multicolumn{1}{|l|}{ SOLAS } & \multicolumn{1}{l}{ LL } & IMDG & \multicolumn{1}{l|}{ FSS } & \multicolumn{1}{l|}{ MLC } & LSA & MARPOL & ISM \\
\hline SOLAS & 1,000 & 3,000 & 9,000 & 2,000 & 5,000 & 5,000 & 7,000 & 4,000 \\
\hline LL & 0,333 & 1,000 & 7,000 & 0,500 & 2,000 & 2,000 & 4,000 & 2,000 \\
\hline IMDG & 0,111 & 0,143 & 1,000 & 0,125 & 0,125 & 0,125 & 0,143 & 0,125 \\
\hline FSS & 0,500 & 2,000 & 8,000 & 1,000 & 3,000 & 2,000 & 6,000 & 3,000 \\
\hline MLC & 0,200 & 0,500 & 8,000 & 0,333 & 1,000 & 1,000 & 5,000 & 1,000 \\
\hline LSA & 0,200 & 0,500 & 8,000 & 0,500 & 1,000 & 1,000 & 5,000 & 1,000 \\
\hline MARPOL & 0,143 & 0,250 & 6,993 & 0,167 & 0,200 & 0,200 & 1,000 & 0,250 \\
\hline ISM & 0,250 & 0,500 & 8,000 & 0,333 & 1,000 & 1,000 & 4,000 & 1,000 \\
\hline
\end{tabular}


Table 7 Result of AHP for EU15 countries of major Maritime regulations

\begin{tabular}{|l|r|r|r|r|r|r|r|r|r|}
\hline \multirow{2}{*}{ COUNTRIES } & \multicolumn{7}{|c|}{ MAJOR MARITIME REGULATIONS } & \multirow{2}{*}{ CR } \\
\cline { 2 - 9 } & SOLAS & LL & DG & FSS & MLC & LSA & MARPOL & ISM & \\
\hline BELGIUM & $32,9 \%$ & $14,0 \%$ & $1,0 \%$ & $20,0 \%$ & $10,0 \%$ & $10,0 \%$ & $3,0 \%$ & $9,0 \%$ & 0,065 \\
\hline DENMARK & $24,0 \%$ & $2,0 \%$ & $2,0 \%$ & $21,0 \%$ & $29,0 \%$ & $9,0 \%$ & $5,0 \%$ & $8,0 \%$ & 0.024 \\
\hline FINLAND & $47,2 \%$ & $23,2 \%$ & $4,9 \%$ & $4,9 \%$ & $4,9 \%$ & $4,9 \%$ & $4,9 \%$ & $4,9 \%$ & 0,078 \\
\hline FRANCE & $34,0 \%$ & $4,0 \%$ & $2,0 \%$ & $24,0 \%$ & $12,0 \%$ & $10,0 \%$ & $5,0 \%$ & $9,0 \%$ & 0,042 \\
\hline GERMANY & $38,5 \%$ & $5,6 \%$ & $2,1 \%$ & $22,4 \%$ & $8,5 \%$ & $3,6 \%$ & $5,3 \%$ & $14,0 \%$ & 0,060 \\
\hline GREECE & $38,0 \%$ & $5,6 \%$ & $1,7 \%$ & $15,4 \%$ & $10,2 \%$ & $15,4 \%$ & $3,4 \%$ & $10,2 \%$ & 0,066 \\
\hline IRELAND & $25,7 \%$ & $4,2 \%$ & $2,0 \%$ & $31,2 \%$ & $4,5 \%$ & $13,9 \%$ & $3,8 \%$ & $14,7 \%$ & 0,051 \\
\hline ITALY & $38,8 \%$ & $2,2 \%$ & $2,8 \%$ & $23,5 \%$ & $7,5 \%$ & $8,3 \%$ & $4,9 \%$ & $12,0 \%$ & 0,090 \\
\hline NETHERLANDS & $39,8 \%$ & $7,3 \%$ & $2,0 \%$ & $21,8 \%$ & $3,3 \%$ & $5,4 \%$ & $7,6 \%$ & $12,8 \%$ & 0,054 \\
\hline PORTUGAL & $38,4 \%$ & $4,0 \%$ & $2,0 \%$ & $13,9 \%$ & $9,8 \%$ & $8,6 \%$ & $3,7 \%$ & $19,6 \%$ & 0,068 \\
\hline SPAIN & $37,4 \%$ & $3,3 \%$ & $2,0 \%$ & $9,8 \%$ & $20,4 \%$ & $6,5 \%$ & $6,3 \%$ & $14,3 \%$ & 0,040 \\
\hline SWEDEN & $37,3 \%$ & $5,5 \%$ & $2,0 \%$ & $11,1 \%$ & $13,6 \%$ & $14,8 \%$ & $3,4 \%$ & $12,3 \%$ & 0,050 \\
\hline UK & $34,8 \%$ & $5,4 \%$ & $1,7 \%$ & $11,2 \%$ & $13,6 \%$ & $8,1 \%$ & $3,2 \%$ & $22,0 \%$ & 0,074 \\
\hline
\end{tabular}

related deficiencies on Fig. 7. Spain, the United Kingdom, and Sweden have fewer remarks compared to the other countries, and remaining countries have a similar number of deficiencies on Fire Safety.

According to the percentage demonstration, Italy has the highest detention ratio (Fig. 8), however AHP approach demonstrate that Italy and Finland have a similar understanding to Dangerous Goods and cargo related deficiencies than the other countries (Fig. 9). The approach for Dangerous Goods has not got utmost priority as other regulations, only few countries has detained ships in accordance with this regulation. Belgium has significantly low detention remarks for cargo-related items compared to the rest of the countries.

The ISM Code has done a significant change in the maritime industry [2]. In accordance with IMDG and FSS Codes, Italy has the highest detention ratio related to ISM Code detentions (Fig. 10). According to spatial demonstration (Fig. 11), United Kingdom, Portugal, and Finland are more likely to detain the vessel ISM caused remarks. In contrast, Belgium, Denmark, and France have similar aspects to the ISM Code. Besides, Ireland, Spain, and Germany are close to the average detention rate.

Table 8 The comparison of International Maritime Regulations by detention results

\begin{tabular}{lllllllll}
\hline SOLAS & LL & IMDG & FSS & MLC & LSA & MARPOL & ISM & TOTAL \\
\hline $33,7 \%$ & $5,6 \%$ & $2,0 \%$ & $20,6 \%$ & $11,2 \%$ & $9,0 \%$ & $4,4 \%$ & $13,5 \%$ & $100 \%$ \\
\hline
\end{tabular}

According to the Fig. 12, Greece has the highest detention ratio related to Load Lines Convention. Significantly, Belgium has the utmost caution for the Load Lines related deficiencies among other countries as result of AHP (Fig. 13). Except for Finland, remaining countries indicate similar results.

LSA Code is one of the vital regulations for the maritime industry. Providing sacred human life at sea has been practicing for a thousand years. For the detention perspective, three countries to come into prominence as Italy, Greece, and Finland according to the percentage demonstration (Fig. 14). In contrast, the AHP results indicate that Netherlands and Germany have significantly low - detention rates for LSA Code related deficiencies (Fig. 15).

MARPOL Convention is crucial to protect the marine environment. After serious accidents, oil spills, and incidents, six annexes of the convention aim to reduce marine pollution from ships. Percentage demonstration indicate that Italy, Greece and Finland have the highest detention percentage (Fig. 16). As spatial analysis indicates, the Netherlands has ultimate awareness for marine pollution, but Belgium has the minimum deficiency rate (Fig. 17). Spain has the second-highest rate for detention rate, and the remaining countries indicate average scores.

Even though the Maritime Labor Convention came into force on 20 August 2013, the ships have been inspected under ILO conventions for years. The percentage analysis result indicates, Italy and Greece have the highest detention ratio (Fig. 18). However, AHP results 

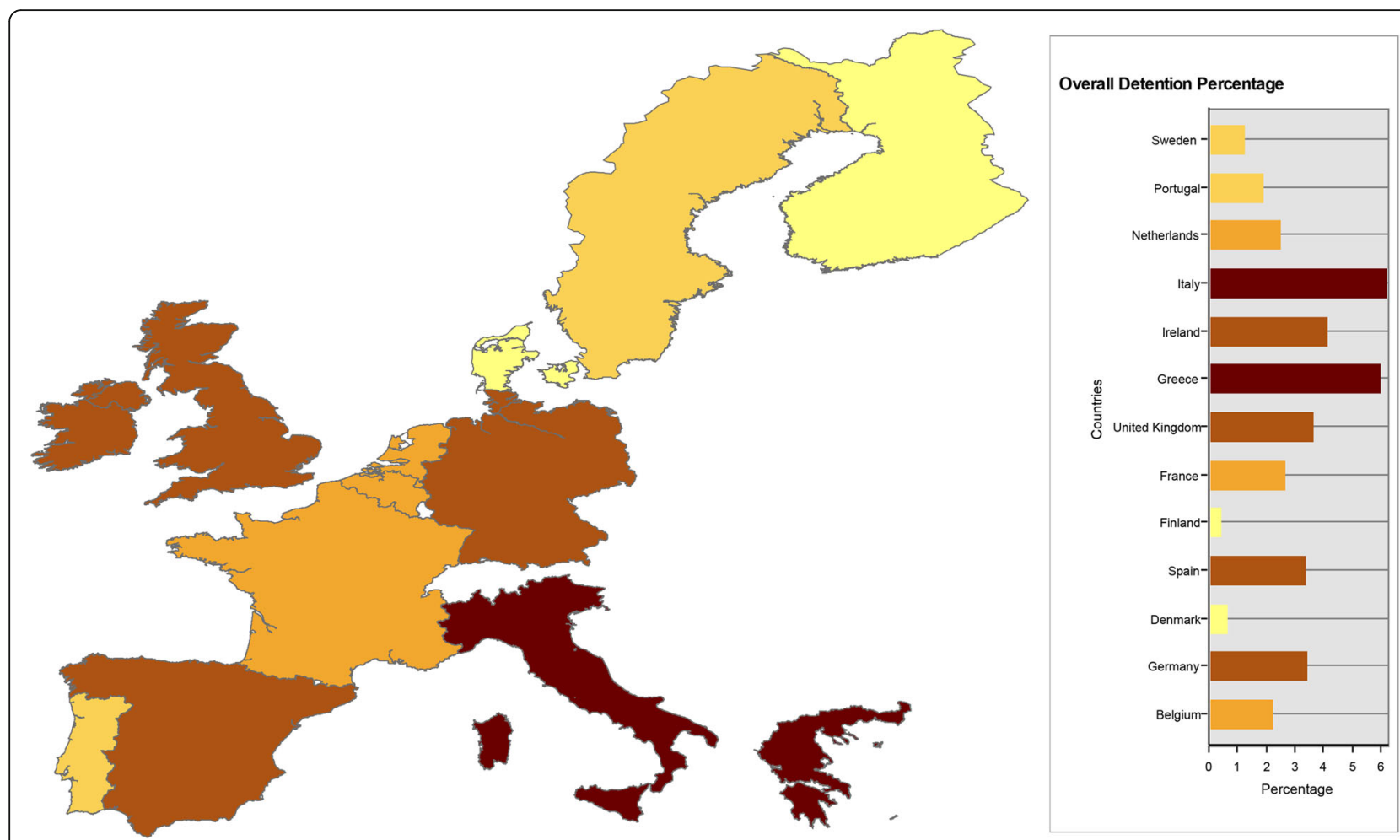

Fig. 3 Overall detention percentage for EU15
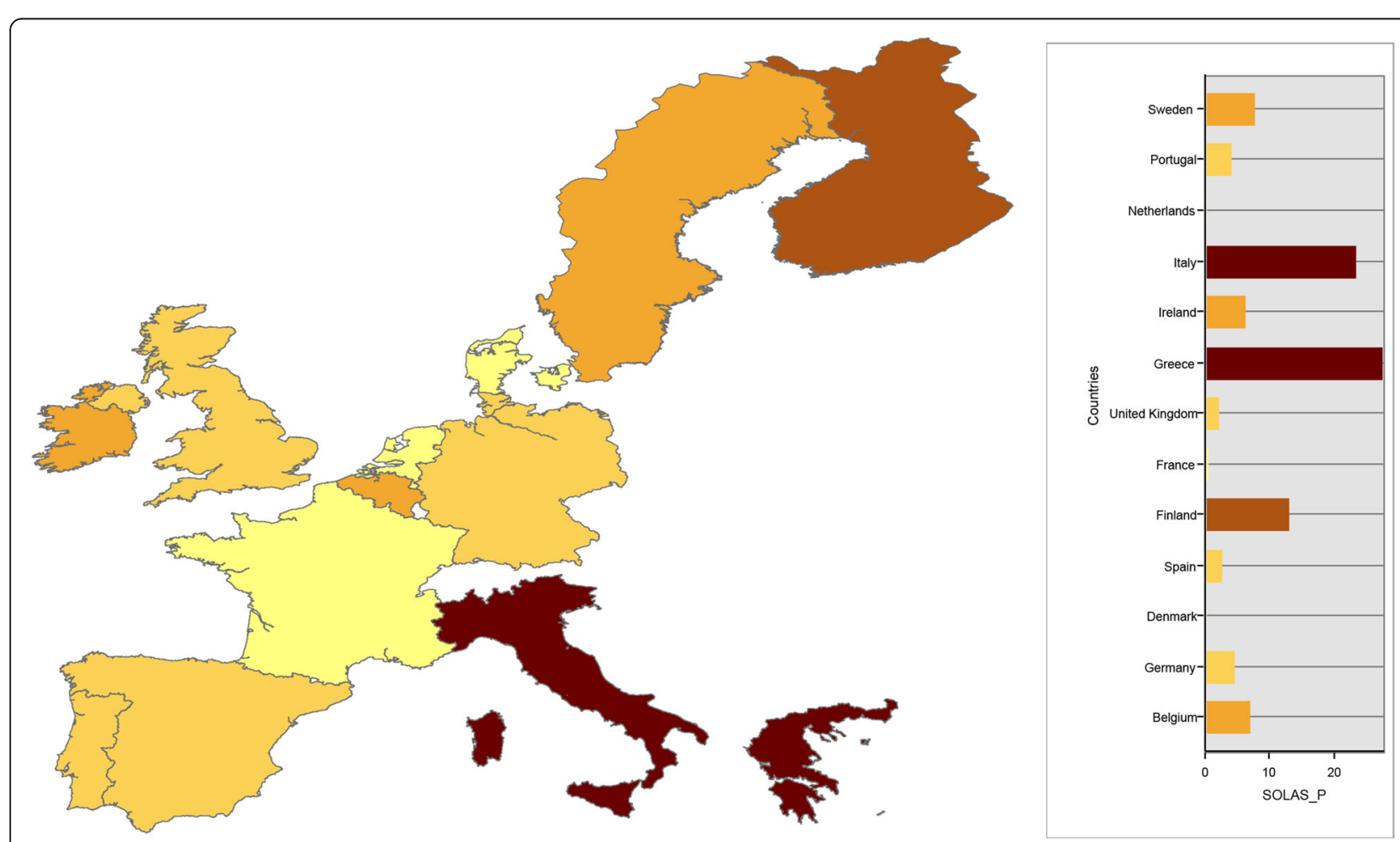

Fig. 4 Detainable remarks percentage for SOLAS Convention for EU15 countries 

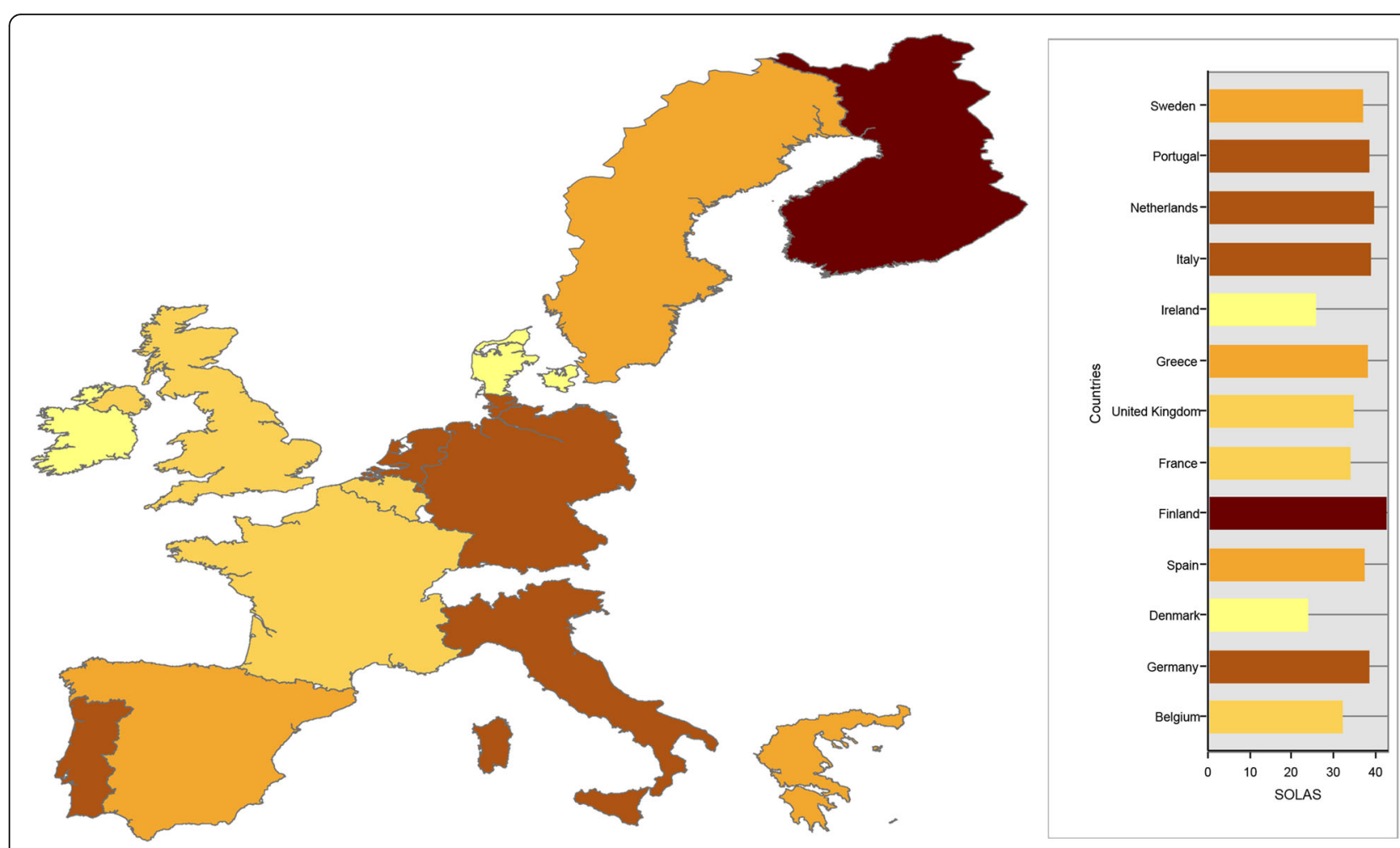

Fig. 5 The weighting of SOLAS Convention deficiencies as a result of AHP
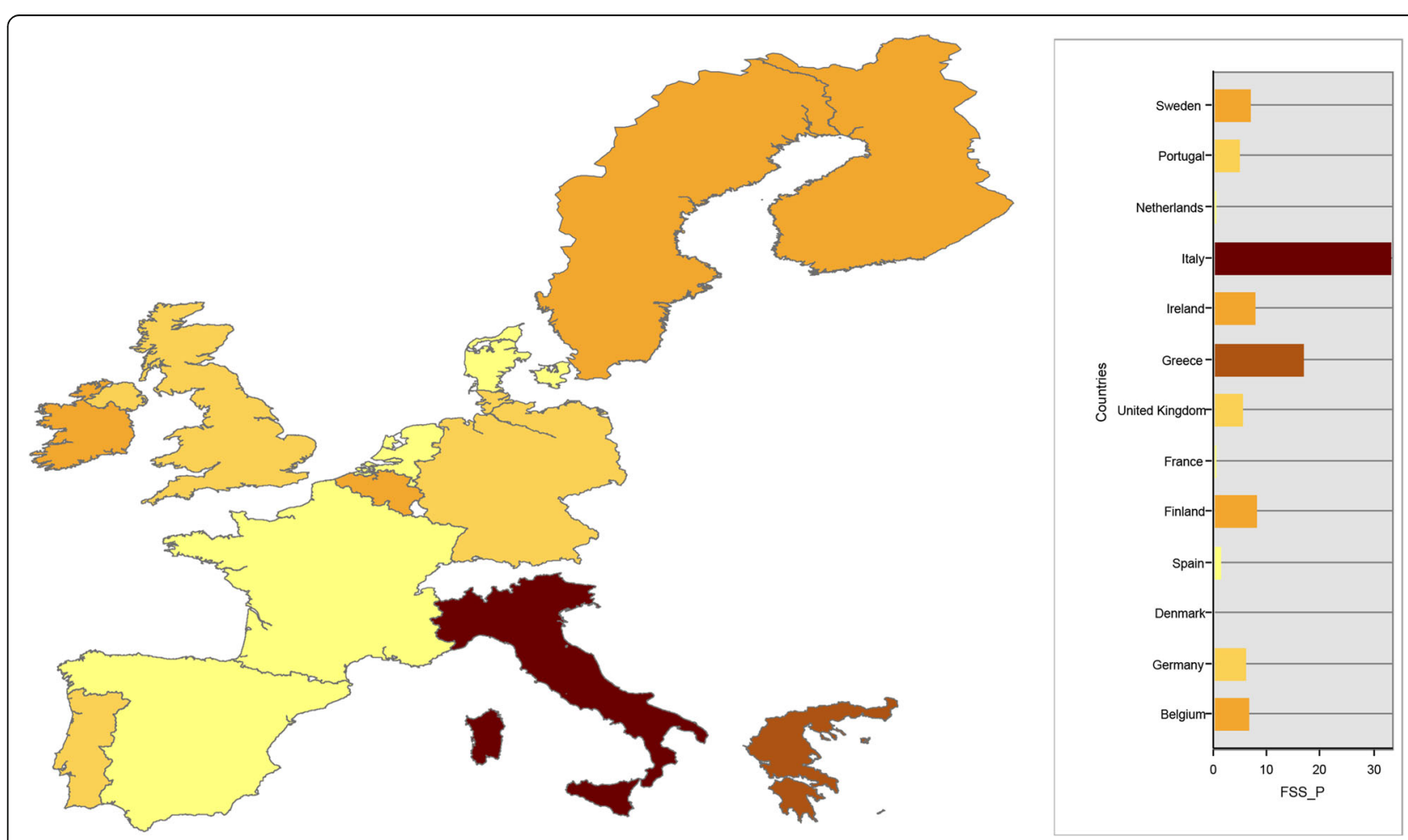

Fig. 6 Detainable remarks percentage for FSS Code for EU15 countries 


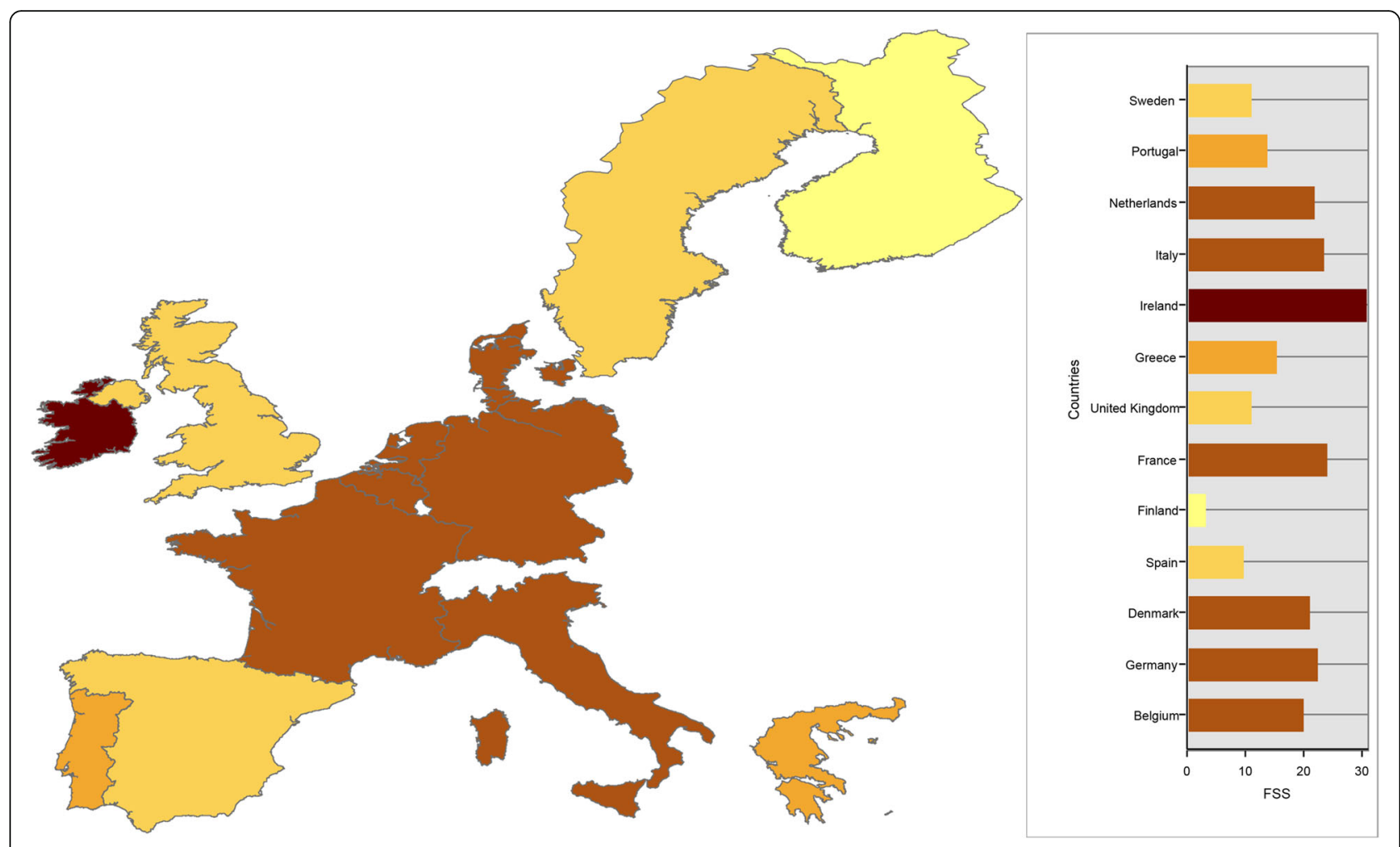

Fig. 7 The weighting of FSS Code deficiencies as a result of AHP
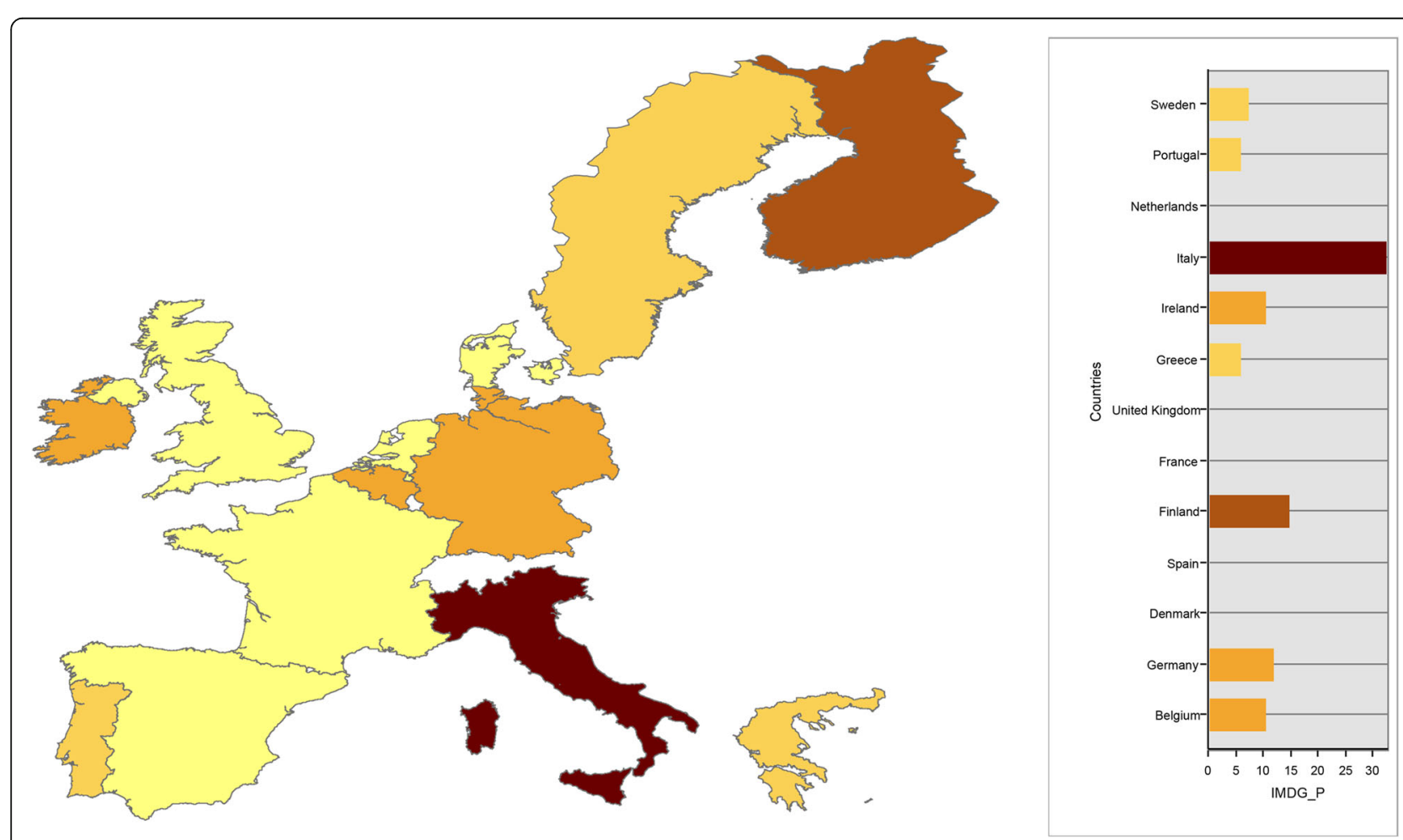

Fig. 8 Detainable remarks percentage for Dangerous Goods for EU15 countries 

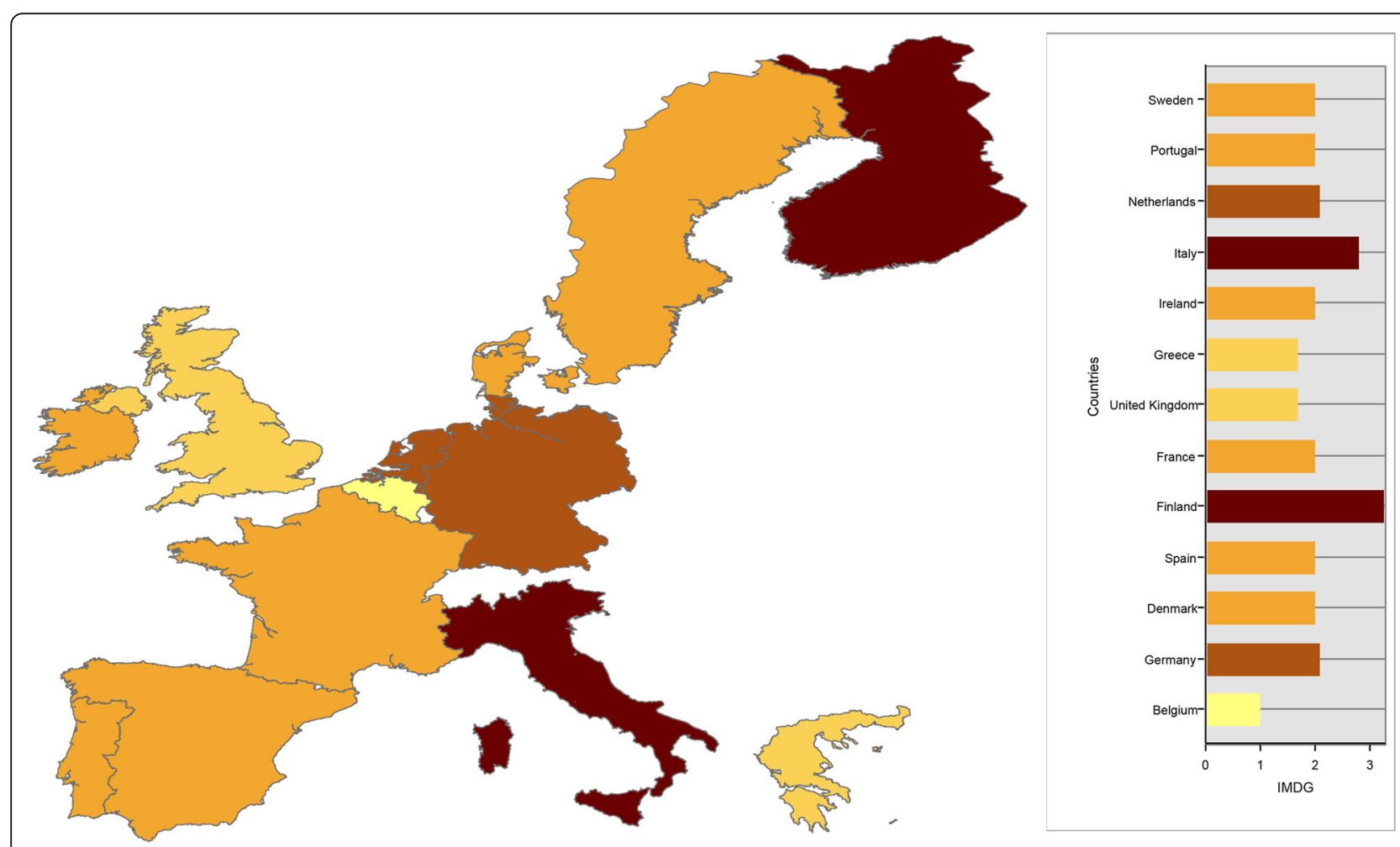

Fig. 9 The weighting of Dangerous Goods deficiencies as a result of AHP
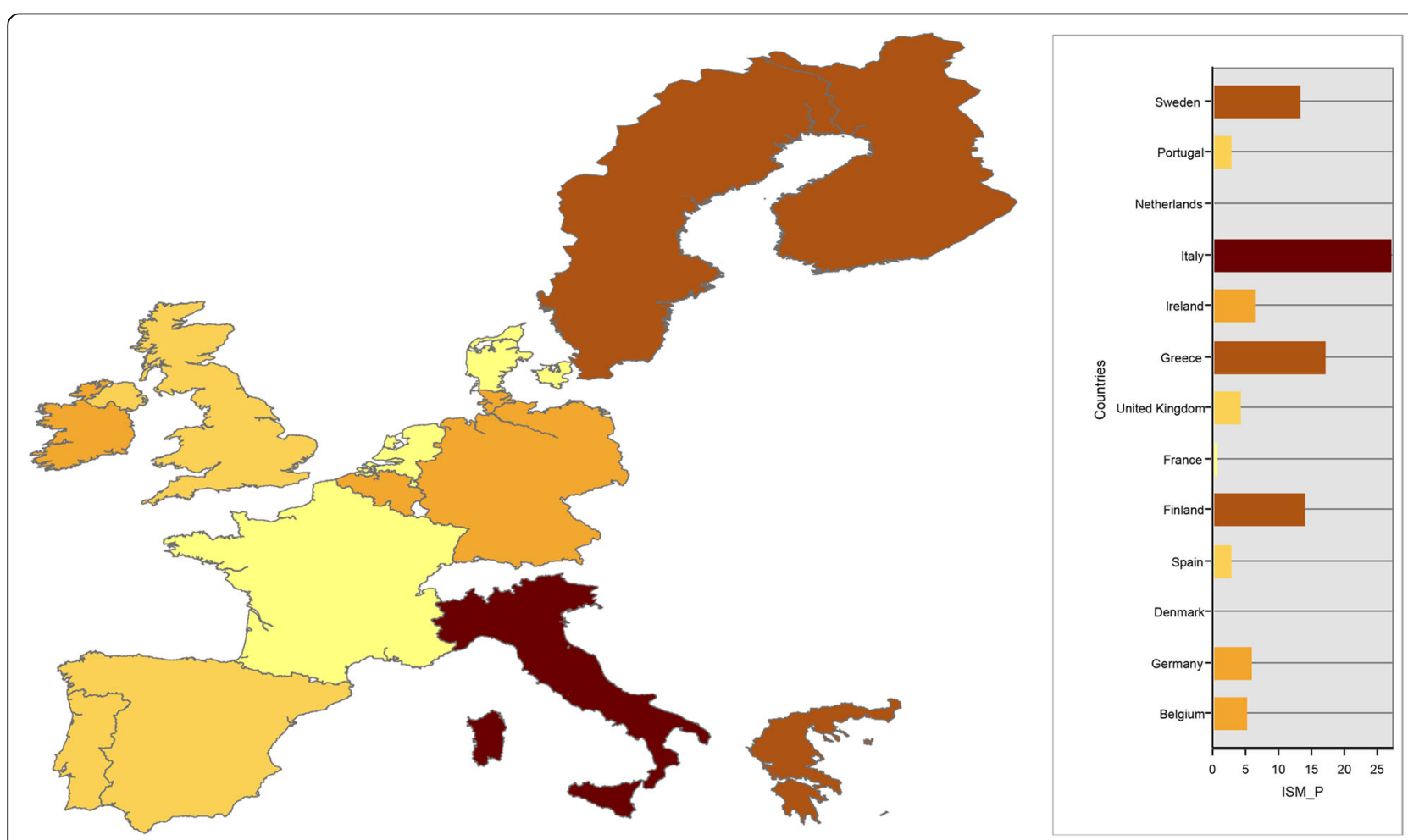

Fig. 10 Detainable remarks percentage for ISM Code for EU15 countries 


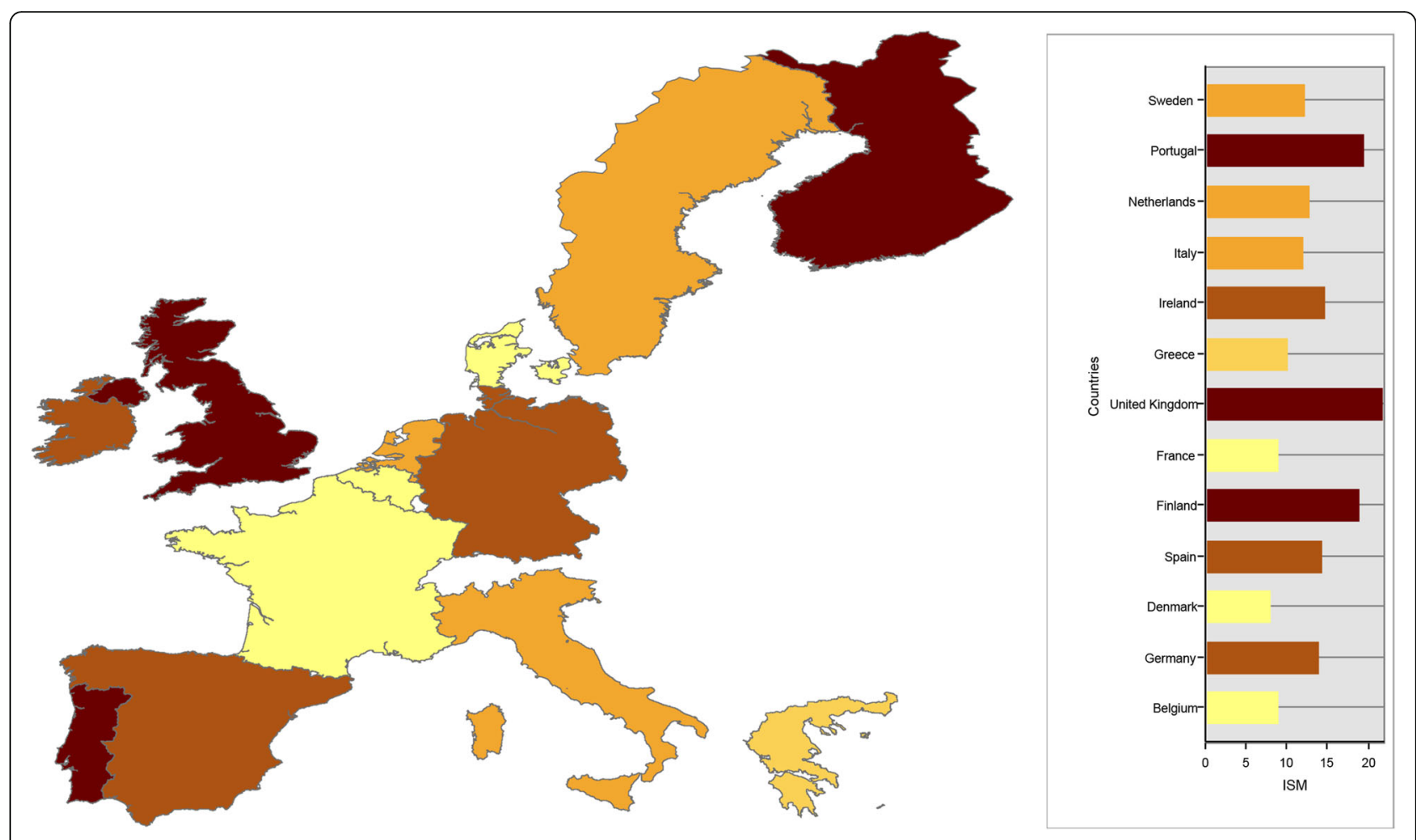

Fig. 11 The weighting of ISM Code deficiencies as a result of AHP
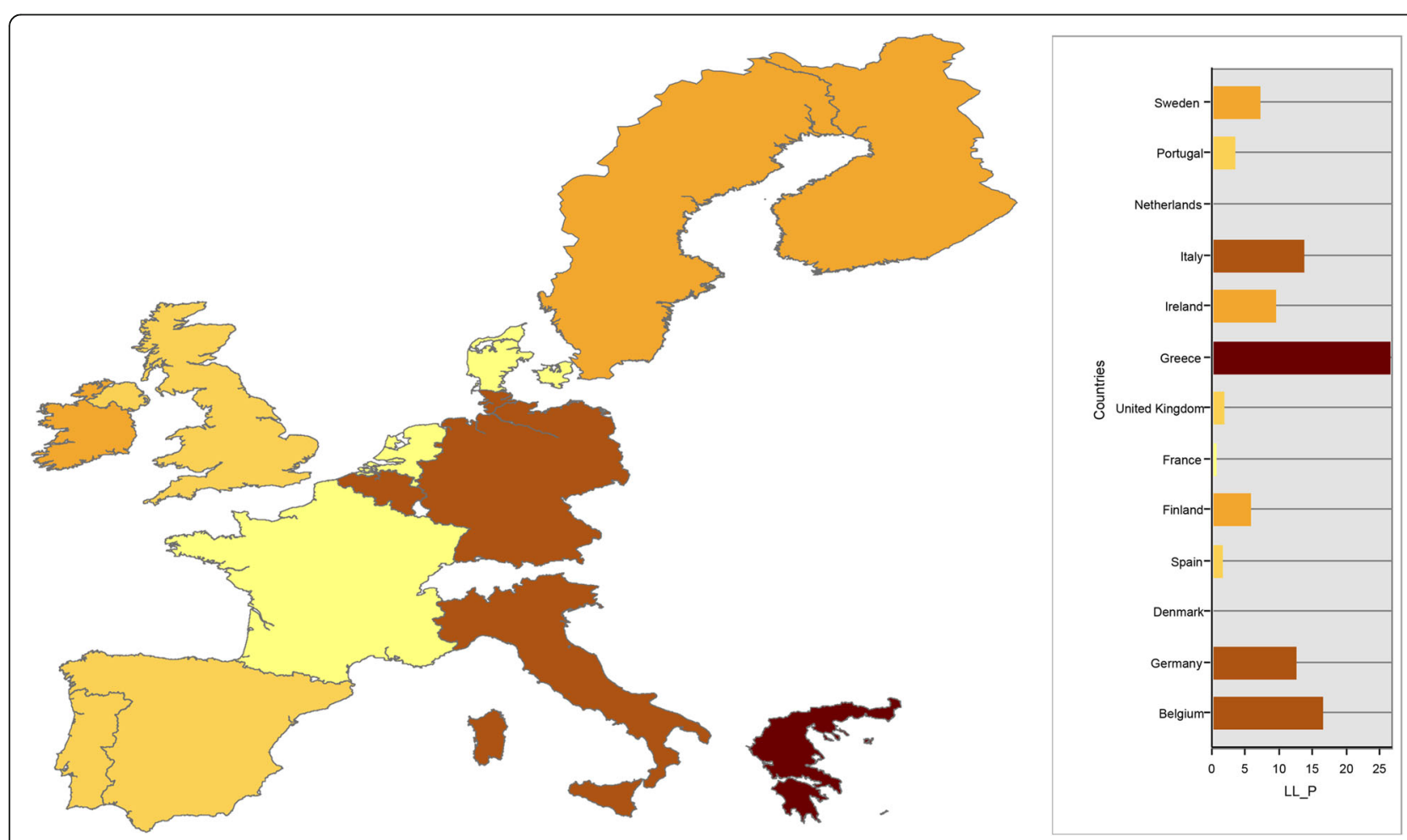

Fig. 12 Detainable remarks percentage for the Load Lines Protocol for EU15 countries 

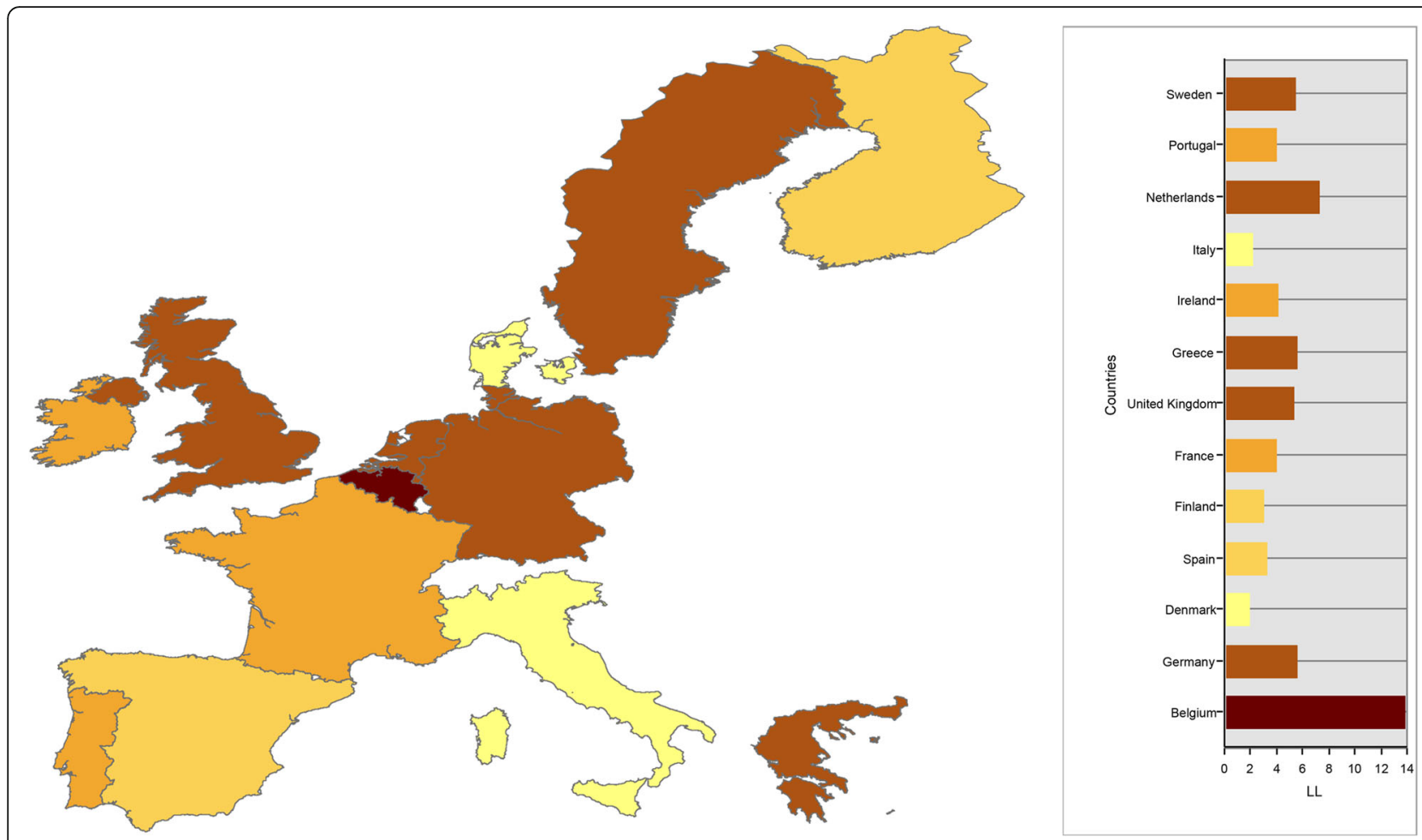

Fig. 13 The weighting of the Load Lines Protocol deficiencies as a result of AHP
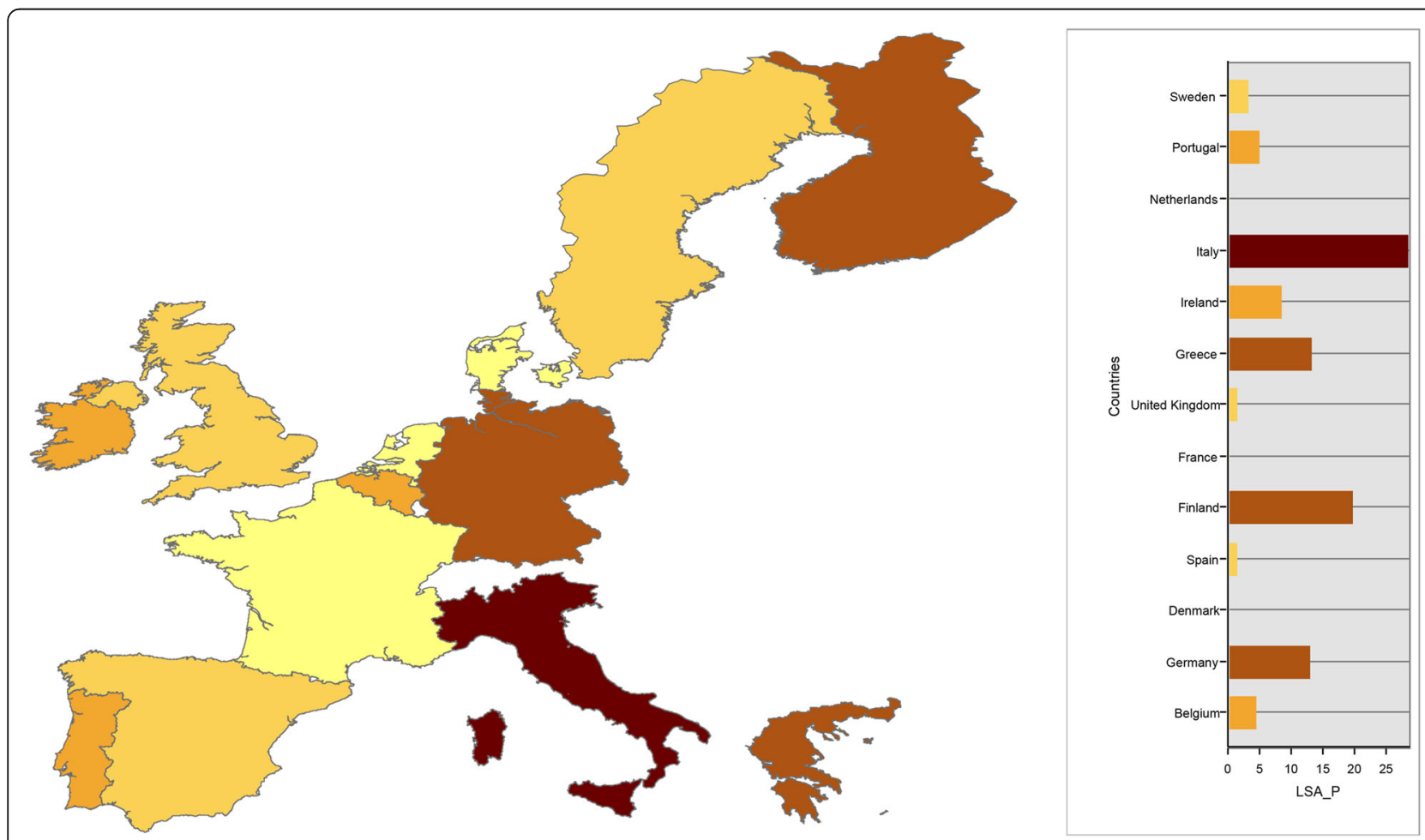

Fig. 14 Detainable remarks percentage for LSA Code for EU15 countries 


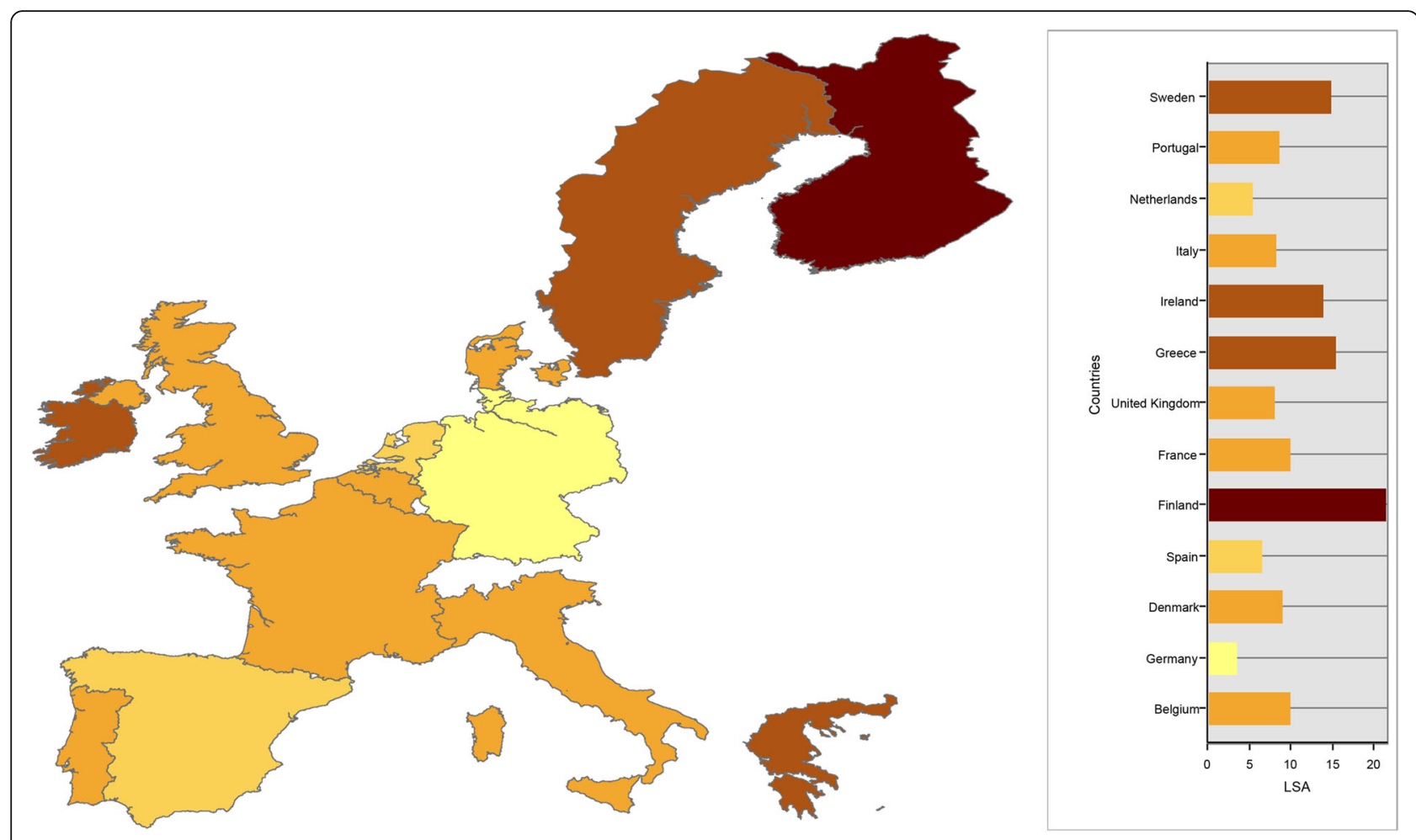

Fig. 15 The weighting of LSA Code deficiencies for EU15 countries as a result of AHP
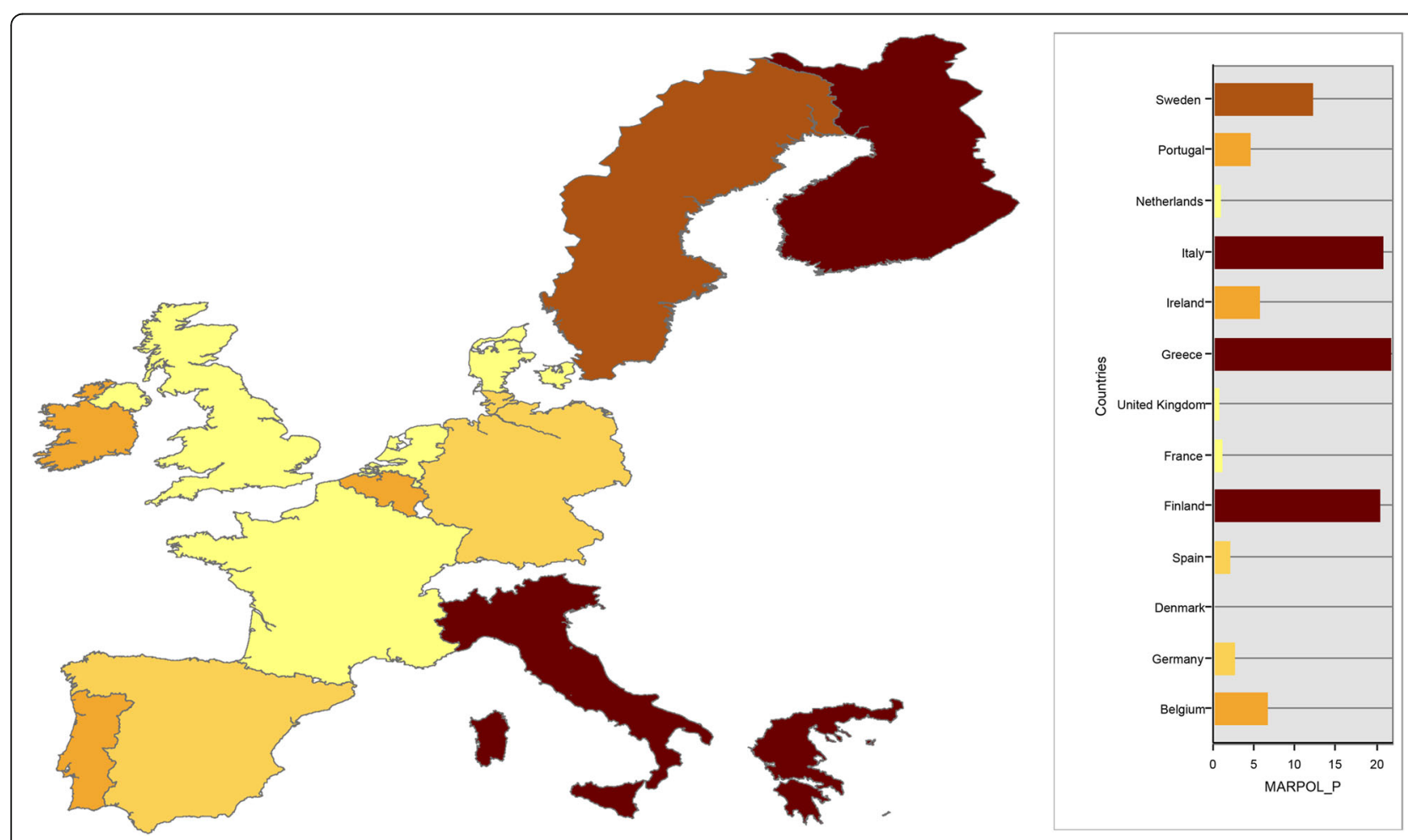

Fig. 16 Detainable remarks percentage for MARPOL Convention for EU15 countries 


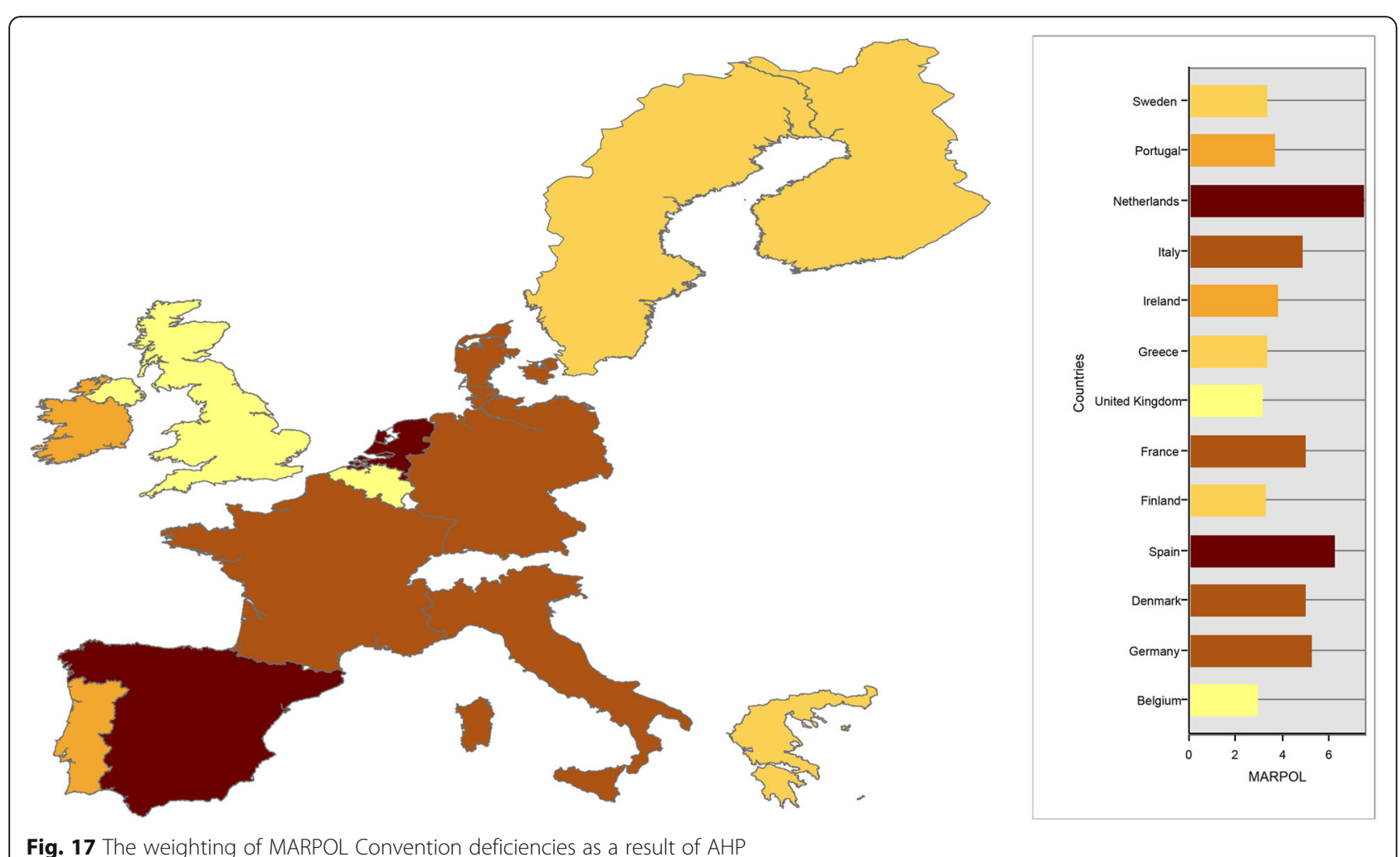

Fig. 17 The weighting of MARPOL Convention deficiencies as a result of AHP
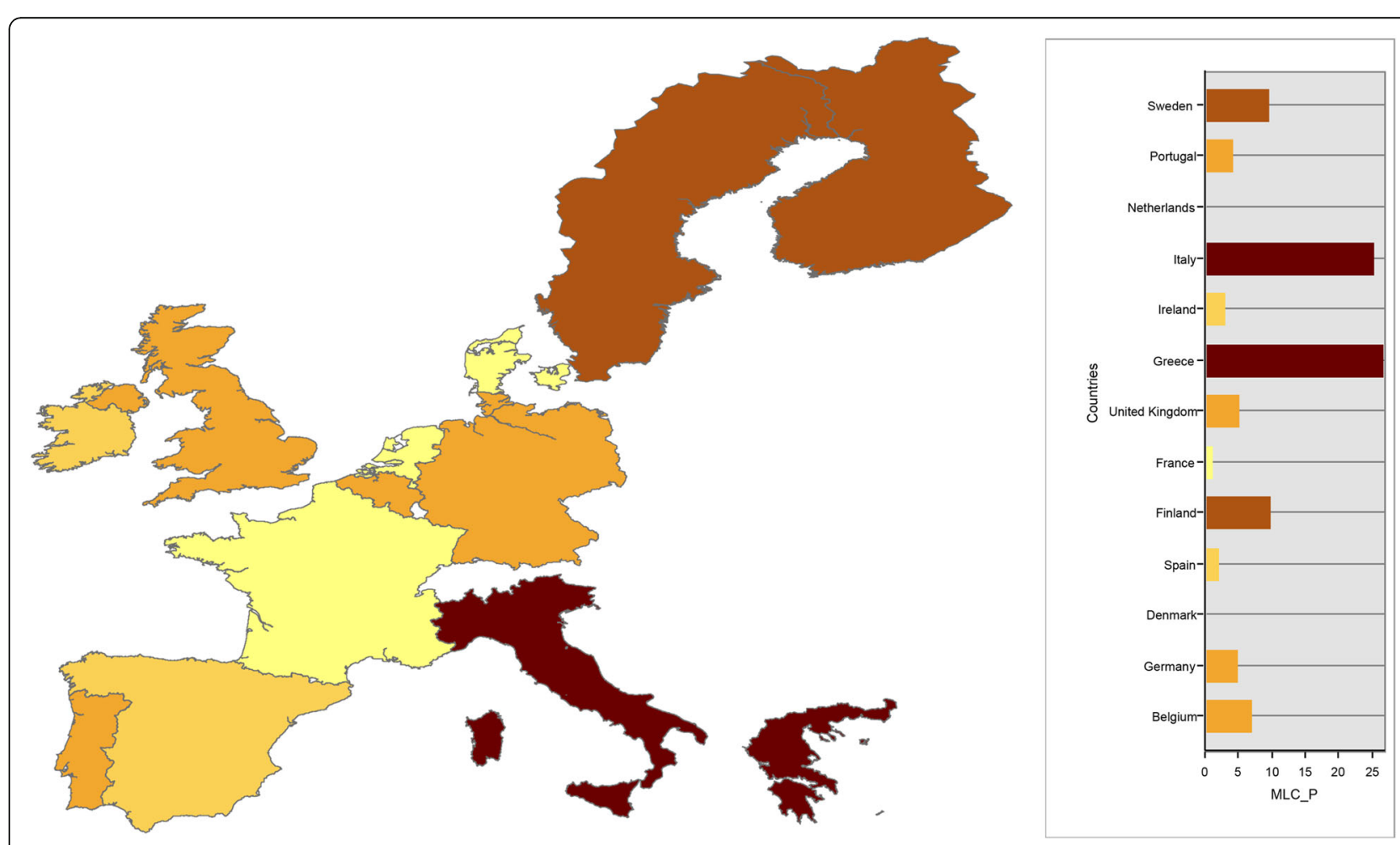

Fig. 18 Detainable remarks percentage for Maritime Labor Convention for EU15 countries 


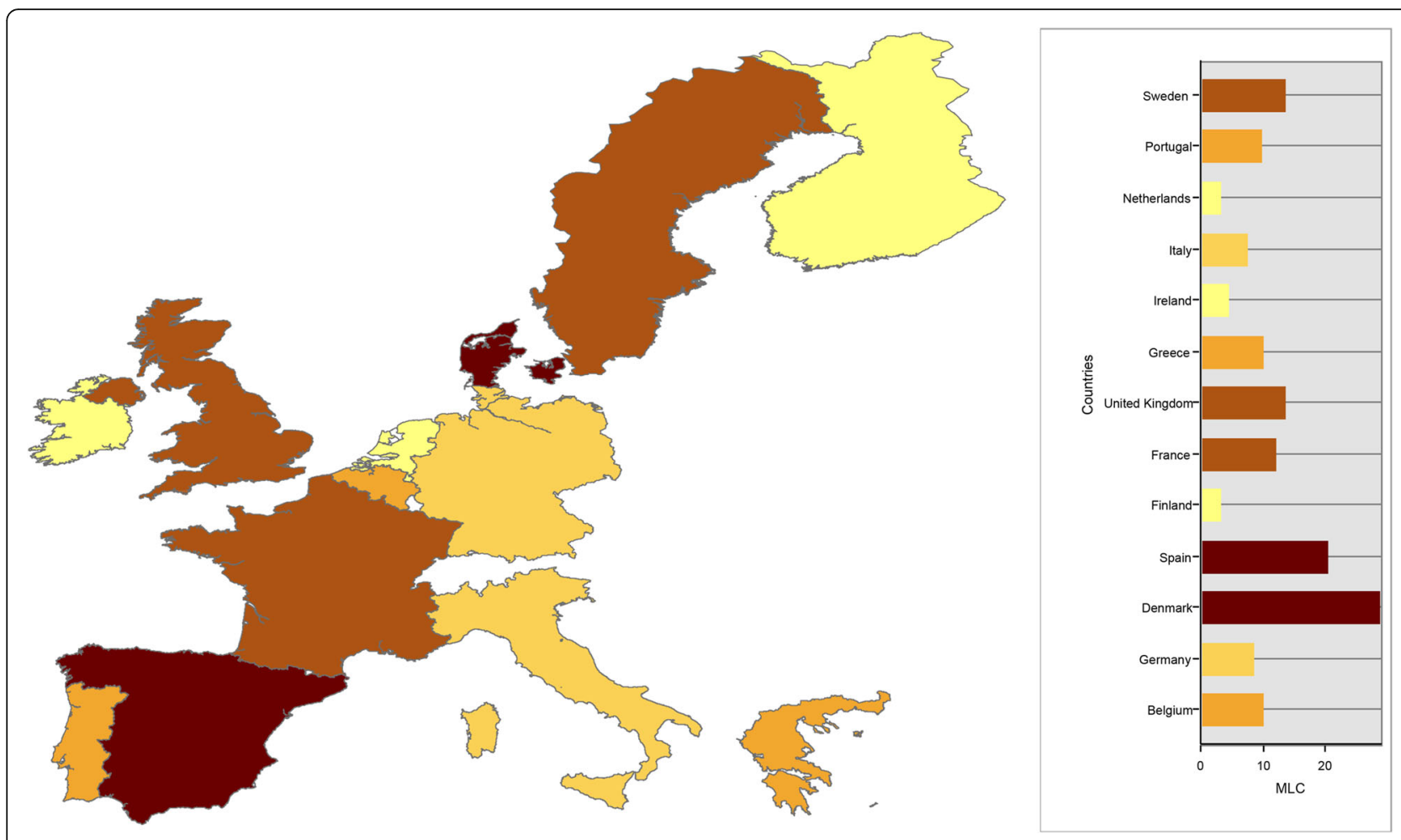

Fig. 19 The weighting of Maritime Labor Convention deficiencies as a result of AHP

indicate that Denmark has the highest detention rate for MLC related deficiencies (Fig. 19). In contrast, the Netherlands, Ireland, and Finland have a similar minimum deficiency rate on detentions.

\section{Conclusion and discussion}

After the serious incidents, Port State Control became a volunteer to almost mandatory action to inspect ships to protect the national environment of coastal states. Inspecting a ship is not a simple target to achieve because of socio-economical varieties, and especially because of the human factor. However, the existing literature and the recent accidents signify that the Port State Control has accomplished a drastic difference in overall safety and environmental pollution prevention.

In this paper, the findings of AHP analysis indicates, remaining countries have different approaches and characteristics on regulations. In this way, the spatial analysis presents us that SOLAS Convention indeed is an essential regulation that causes detention for EU15 countries. For instance, the study reveals that Belgium Port State Control Officers consider Load Line related deficiencies more than the rest of the states, and FSS Code is an important detention deficiency, even more than the SOLAS Convention. Likewise, Italy and Finland have the same approach to Dangerous Goods related deficiencies, and the United Kingdom detains the vessels because of ISM
Code deficiencies. Moreover, LSA Code deficiencies are essential for Greece, Sweden, and Ireland to detain the ships. Netherlands has the utmost importance on the MARPOL Convention, and the majority inspection records indicate, the root cause of the detention is a violation of Air Pollution Regulations. Denmark detention deficiencies show Maritime Labor Convention (formerly ILO) deficiencies are more likely to bring detention for ships. The critical importance of AHP for this analysis to include zero detention remarks for countries. For instance, there is no detention for Load Line Convention in Denmark. This is not mean that any vessel has a Port State Control in Denmark with major Load Line deficiency will not subject detention, and each convention has its own value even though there is no detention.

This study also emphasizes that the Port State Control Officers under Paris MOU have various backgrounds, and individuals have a different aspect of detaining the ships with deficiencies under professional judgement. In relation, each country has a variable detention profile for ships due to port state control officer's background, and the human factor behind professional judgment on detention decision since the goal of international legislation/ regulation is harmonized. Transition of AHP results on GIS analysis demonstrates country profile and characteristics for overall ship detentions. In this way, ship owners/ managers and policymakers may evaluate 
their self-awareness on Port State Controls and their country characteristics on detainable deficiencies. At this juncture, with the spatial analysis, this paper lead these interested parties to gain knowledge which member state has more attention on which international regulation by detaining the visiting ship under the New Inspection Regime (NIR). Practical implication of this knowledge will contribute self-awareness and analytical approach on consequences of detentions, thereby enhances maritime safety and security. For instance, no detention found related to ISPS Code, for EU15 countries raises questions regarding implementation of security regulations.

The analysis of Port State Control inspection results indicates that sometimes even Port State Control is not strong enough to fight against substandard vessels [20]. Individual inspections for Port State Control indicates remarkable results; however, the point of view may mislead the results since there are 207 coastal countries. The Port States are in the formation of Memorandum of Understandings. By this means, limitation of this paper based on EU15 member Paris MOU countries and due to detained ships are not weighted related to their type, Flag, Recognized Organizations, and manager risk profiles as NIR does, all ships were assumed to be equal on selected maritime regulations. Moreover, other essential regulations (e.g., Tonnage Convention, STCW Code, COLREG) excluded because of their deficiency codes.

Considering to the findings of this paper and its limitations, future studies may focus on all Paris MOU member countries taking account into the sub-category of the deficiencies. Comparing all MOU's will also provide an overall understanding of where ships become substandard and reasons why they become substandard. In addition to the Port State Control reports, interviews with PSCOs and further qualitative studies indicating their viewpoints, and comparison of these interviews with the findings of this study may lead us to contribute the literature to by critiquing the consistency in decision of detention through human factor.

\section{Acknowledgements}

Not applicable.

\section{Authors' contributions}

The work was a joint project of both authors. All authors read an approved the final manuscript.

\section{Funding}

Not applicable.

\section{Availability of data and materials}

The data sets used and/or analyzed during the current study are available from public Paris MOU website. We would like to declare that the data of this article is available upon request and includes no conflict of interest. All data has taken from public website of Paris MOU.

\section{Declarations}

\section{Competing interests}

The authors declare that they have no competing interests.

Received: 21 January 2020 Accepted: 9 March 2021

Published online: 25 March 2021

\section{References}

1. Anon. n.d. "Why does the EU need the European maritime safety agency?" Retrieved May 14, 2019 (http://www.emsa.europa.eu/emsa-homepage/80-a bout/60-why-does-the-eu-need-the-european-maritime-safety-agency.html).

2. Bhattacharya, S. (2012). The effectiveness of the ISM code: A qualitative enquiry. Marine Policy, 36(2), 528-535. https://doi.org/10.1016/j.marpol.2011. 09.004.

3. Bolat, F., \& Guler, N. (2015). Hub port potential of Marmara region in Turkey by network-based Modelling. Proceedings of the Institution of Civil Engineers Transport, 168(2), 172-187. https://doi.org/10.1680/tran.13.00043.

4. Cariou, P., Mejia, M. Q., \& Wolff, F.-C. (2008). On the effectiveness of port state control inspections. Transportation Research Part E: Logistics and Transportation Review, 44(3), 491-503. https://doi.org/10.1016/j.tre.2006.11.005.

5. Cariou, P., Mejia, M. Q., \& Wolff, C. F. (2009). Evidence on target factors used for port state control inspections. Marine Policy, 33(5), 847-859. https://doi. org/10.1016/j.marpol.2009.03.004.

6. Cariou, P., \& Wolff, F.-C. (2015). Identifying substandard vessels through port state control inspections: A new methodology for concentrated inspection campaigns. Marine Policy, 60, 27-39. https://doi.org/10.1016/j.marpol.2015.05.013.

7. Giamalaki, M., \& Tsoutsos, T. (2019). Sustainable siting of solar power installations in Mediterranean using a GIS/AHP approach. Renewable Energy, 141, 64-75. https://doi.org/10.1016/j.renene.2019.03.100.

8. Graziano, A., Cariou, P., Wolff, F.-C., Mejia, M. Q., \& Schröder-Hinrichs, J.-U. (2018). Port state control inspections in the European Union: Do Inspector's number and background matter? Marine Policy, 88, 230-241. https://doi. org/10.1016/j.marpol.2017.11.031.

9. Hare, J. (1997). Port state control: Strong medicine to cure a sick industry. Georgia Journal of International and Comparative Law, 26(3), 571-594.

10. Hozairi, H., Buhari, B., Lumaksono, H., \& Tukan, M. (2019). Determining the influencing factors of the Indonesian maritime security using analytical hierarchy process. Jurnal Pertahanan: Media Informasi Ttg Kajian \& Strategi Pertahanan Yang Mengedepankan Identity, Nasionalism \& Integrity, 5(3), 6576. https://doi.org/10.33172/.jp.v5i3.532.

11. Jones, N. (2013). The Plimsoll sensation: The great campaign to save lives at sea. Little, Brown Book Group.

12. Jung, H., Kim, J., \& Shin, K. S. (2019). Importance analysis of decision making factors for selecting international freight transportation mode. The Asian Journal of Shipping and Logistics, 35(1), 55-62. https://doi.org/10.1016/j.ajsl.2 019.03.008.

13. Kandakoglu, A., Celik, M., \& Akgun, I. (2009). A multi-methodological approach for shipping registry selection in maritime transportation industry. Mathematical and Computer Modelling, 49(3-4), 586-597. https://doi.org/10.1 016/j.mcm.2008.09.001

14. Keselj, T. (1999). Port state jurisdiction in respect of pollution from ships: The 1982 United Nations convention on the law of the sea and the memoranda of understanding. Ocean Development \& International Law, 30(2), 127-160. https://doi.org/10.1080/009083299276212.

15. Kiehne, G. (1996). Investigation, detention and release of ships under the Paris memorandum of understanding on port state control: A view from practice. The International Journal of Marine and Coastal Law, 11(2), 217-224. https://doi.org/10.1163/157180896X00087.

16. Knapp, S., Bijwaard, G., \& Heij, C. (2011). Estimated incident cost Savings in Shipping due to inspections. Accident; Analysis and Prevention, 43(4), 15321539. https://doi.org/10.1016/j.aap.2011.03.005.

17. Knapp, S., \& Franses, P. H. (2007). Econometric analysis on the effect of port state control inspections on the probability of casualty. Marine Policy, 31(4), 550-563. https://doi.org/10.1016/j.marpol.2006.11.004.

18. Liou, S.-t., Liu, C.-P., Chang, C.-C., \& Yen, D. C. (2011). Restructuring Taiwan's port state control inspection authority. Government Information Quarterly, 28(1), 36-46. https://doi.org/10.1016/j.giq.2010.05.005.

19. Masroeri, A. A., Artana, K. B., Pitana, T., \& Putranta, D. D. (2012). A review on some research issues on AIS to improve the ship safety operation at sea. Journal of Maritime Researches, 2(2012-03), 11-23. 
20. Payoyo, P. B. (1994). Implementation of international conventions through port state control: An assessment. Marine Policy, 18(5), 379-392. https://doi. org/10.1016/0308-597X(94)90034-5.

21. Ravira, F. J., \& Piniella, F. (2016). Evaluating the impact of PSC inspectors' professional profile: A case study of the Spanish maritime administration. WMU Journal of Maritime Affairs, 15(2), 221-236. https://doi.org/10.1007/ s13437-015-0096-y.

22. Rodríguez, E., and F. Piniella. 2012. "The new inspection regime of the Paris Mou on port state control: Improvement of the system." (1):7.

23. Saaty, T. L. (2008). Decision making with the analytic hierarchy process. International Journal of Services Sciences, 1(1), 83. https://doi.org/10.1504/ IJSSCI.2008.017590.

24. Saaty, T. L., \& Vargas, L. G. (2012). Models, methods, Concepts \& Applications of the analytic hierarchy process, (2nd ed., ). New York: Springer. https://doi. org/10.1007/978-1-4614-3597-6

\section{Publisher's Note}

Springer Nature remains neutral with regard to jurisdictional claims in published maps and institutional affiliations.

\section{Submit your manuscript to a SpringerOpen ${ }^{\circ}$ journal and benefit from:}

- Convenient online submission

- Rigorous peer review

- Open access: articles freely available online

- High visibility within the field

- Retaining the copyright to your article

Submit your next manuscript at $\boldsymbol{\nabla}$ springeropen.com 